\title{
The road to adolescent traffic safety is paved with good intentions
}

Citation for published version (APA):

Feenstra, H. (2011). The road to adolescent traffic safety is paved with good intentions. [Doctoral Thesis, Maastricht University]. https://doi.org/10.26481/dis.20110916hf

Document status and date:

Published: 01/01/2011

DOI:

10.26481/dis.20110916hf

Document Version:

Publisher's PDF, also known as Version of record

\section{Please check the document version of this publication:}

- A submitted manuscript is the version of the article upon submission and before peer-review. There can be important differences between the submitted version and the official published version of record.

People interested in the research are advised to contact the author for the final version of the publication, or visit the DOI to the publisher's website.

- The final author version and the galley proof are versions of the publication after peer review.

- The final published version features the final layout of the paper including the volume, issue and page numbers.

Link to publication

\footnotetext{
General rights rights.

- You may freely distribute the URL identifying the publication in the public portal. please follow below link for the End User Agreement:

www.umlib.nl/taverne-license

Take down policy

If you believe that this document breaches copyright please contact us at:

repository@maastrichtuniversity.nl

providing details and we will investigate your claim.
}

Copyright and moral rights for the publications made accessible in the public portal are retained by the authors and/or other copyright owners and it is a condition of accessing publications that users recognise and abide by the legal requirements associated with these

- Users may download and print one copy of any publication from the public portal for the purpose of private study or research.

- You may not further distribute the material or use it for any profit-making activity or commercial gain

If the publication is distributed under the terms of Article $25 \mathrm{fa}$ of the Dutch Copyright Act, indicated by the "Taverne" license above, 


\section{The Road to}

Adolescent Traffic

Safety is Paved with Good Intentions 


\section{Colophon}

Cover design: Rudi Jonker (www.rudijonker.nl)

Graphic design: Anouk Bouten (www.anoukbouten.nl)

Production: Ipskamp Drukkers (www.ipskampdrukkers.nl)

Copyright $\odot 2011$ Hans Feenstra

ISBN 978-90-9026251-2

All rights are reserved. No part of this book may be reproduced or transmitted in any form or by any means, without written permission from the author or, when appropriate, the publisher of the article. 


\title{
The Road to
}

\section{Adolescent Traffic Safety is}

\author{
Paved with
}

\section{Good Intentions}

\section{PROEFSCHRIFT}

ter verkrijging van de graad van doctor aan de Universiteit Maastricht, op gezag van de Rector Magnificus, Prof. mr. G.P.M.F. Mols volgens het besluit van het College van Decanen, in het openbaar te verdedigen op vrijdag 16 september 2011 om 10.00 uur

door

Hans Feenstra 


\section{Promotor}

Prof. dr. G. Kok

\section{Copromotor}

Dr. R.A.C. Ruiter

\section{Beoordelingscommissie}

Prof. dr. B. van den Borne (voorzitter)

Prof. dr. R.M. Meertens

Prof. dr. J. Ramaekers

Prof. dr. J. Thatcher Shope (University of Michigan)

Prof. dr. G. Wets (Universiteit Hasselt)

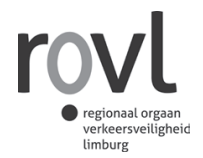

The research presented in this dissertation was supported by the Regional Organ Traffic Safety Limburg (ROVL, Maastricht). 


\section{Contents}

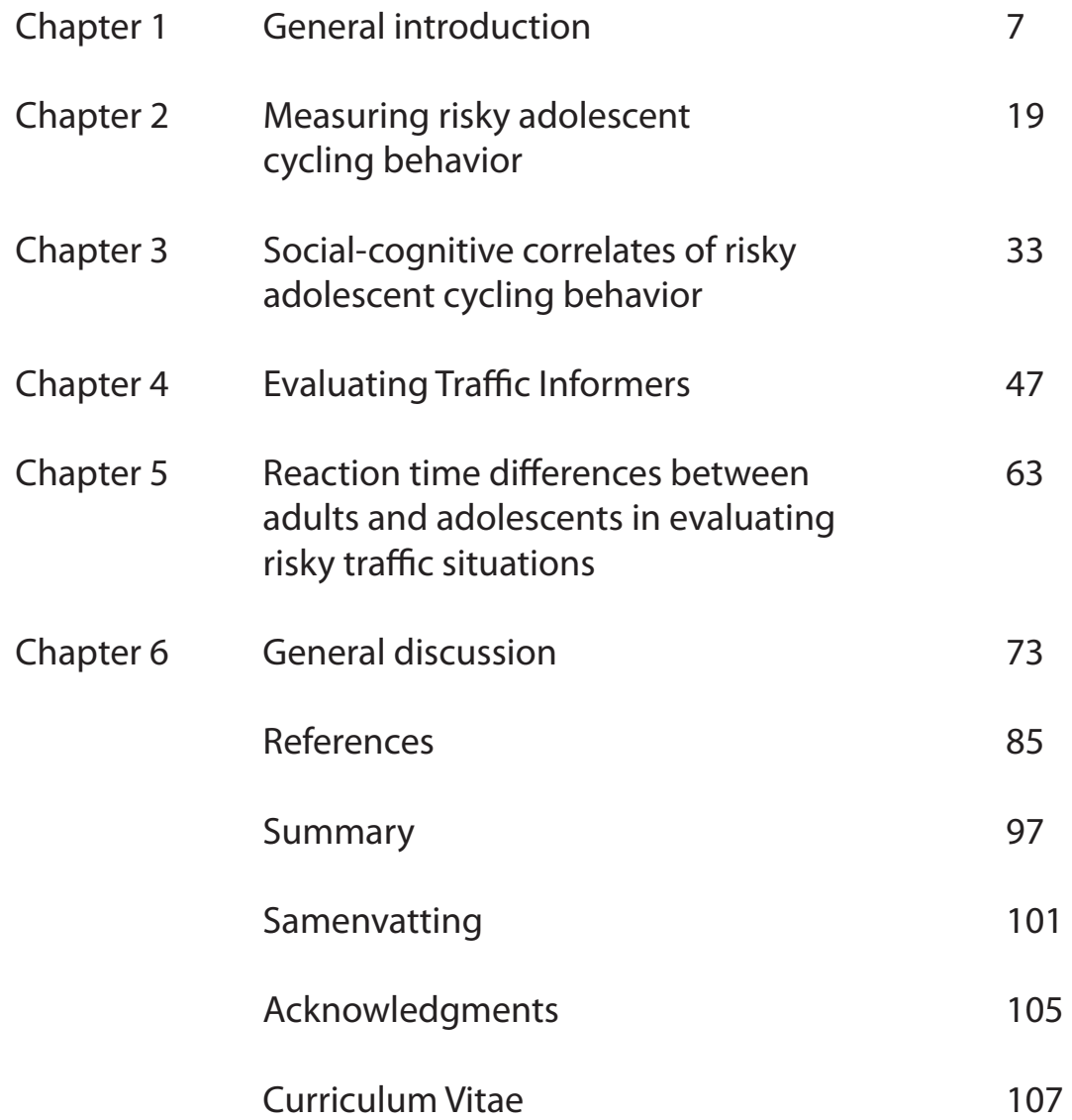



Chapter 1

General
introduction 
Glasgow, 1842, the inventor of the pedal-driven bicycle Kirkpatrick McMillian, riding on his own invention, knocks over a little girl and is fined five British shillings. It's the first recorded bicycle accident, even though the report is vague and the identification disputed. The first recorded traffic fatality in history occurred some decades later when on August 31 1869, a young woman named Mary Ward was thrown from her seat on a steam carriage when it suddenly jolted at a corner. She was crushed by one of the wheels after which she died almost instantly (Fallon \& O'Neill, 2005). Since then, traffic accidents have become one of the world's most important causes of death worldwide. In fact, traffic accidents are the number one cause of death for adolescents (ages 15 - 24) in Europe (European Road Safety Observatory, 2006) as well as the United States (National Vital Statistics Report, 2002) and the Netherlands (SWOV, 2010).

The Netherlands is nevertheless a safe country. In fact, the Netherlands is the second safest country in Europe with 43 traffic fatalities per million inhabitants in 2008, surpassed only by Malta with 29 traffic fatalities and closely followed by the United Kingdom with 50 traffic fatalities. For reference, the European average was 80 fatalities per million inhabitants (Eurostat, 2009). Traffic fatalities in the Netherlands have been steadily declining the last couple of decades. For instance, only ten years ago the Netherlands had almost twice the amount of fatalities in traffic. However, the decline in annual fatalities appears to have come to a standstill. In 2008 a total of 750 people died in traffic in the Netherlands, and a large proportion of those were younger than 24 years of age (26\%; DVS, 2008).

Among other things, the Dutch are known for their use of bicycles. An estimated 8 out of 10 Dutchmen and women own a bike (Lynam et al., 2005) and more than $25 \%$ of all trips are made by bike (compared to $1 \%$ in the U.K. and the US; Pucher \& Buehler, 2008). Especially for secondary school students (ages $12-17$ years) the bicycle is the most important mode of transport. Students use their bicycle for as much as half of all their journeys (Wegman \& Aarts, 2006). Even though cycling is considered healthy (Basset Jr., Pucher, Buehler, Thompson, \& Crouter, 2008), bicycle use does entail relatively high safety and health risks (DVS, 2008; SWOV, 2006), and accident analyses have shown that adolescents are particularly prone to be involved in traffic accidents.

Adolescence is broadly defined: Possible age ranges vary between 10 and 24 years of age (WHO; Van Dale, 2008). Adolescence constitutes the period between childhood and adulthood; the period when a child becomes physically mature, but not yet emotionally. Dahl (2004) defines adolescence as the period between sexual maturation and attainment of adult roles and responsibility. The onset of adolescence is marked by puberty, the period in which boys and girls go through 
biological changes, and continues until their brain is fully matured (somewhere between the twentieth and thirtieth year). However, the term adolescence is more often than not used to describe people in their teens.

In the Netherlands, each year over 170 adolescents are killed in traffic and three thousand are hospitalized, accounting for $21 \%$ and $19 \%$ of all traffic fatalities and injuries respectively, whereas they account for only $12 \%$ of the population (DVS, 2008). In other words, adolescents are twice as likely to get into an accident as you would expect from their proportion in the population. This is not only the case in the Netherlands, but similar results can be found in Europe (European Road Safety Observatory, 2007) and the United States (Sleet \& Ballesteros, 2009).

Despite the relative safety of the Dutch roads, there are too many accidents that can be prevented and with that many fatalities and hospitalizations. The organization responsible for the prevention of road accidents in the province of Limburg is the Regional Organ Traffic Safety Limburg (Regionaal Orgaan Verkeersveiligheid Limburg; ROVL). The goal of the ROVL is to reduce the amount of traffic accident victims and fatalities to zero, through evidence-based practice and research. In line with this goal the ROVL embraces a scientific view on currently used traffic safety education programs. Maastricht University was asked to evaluate a popular education program aimed at secondary school students, Traffic Informers. The result of this evaluation is subject of this thesis.

In this thesis the focus lies on secondary school students who are not yet of legal age to drive cars, thus who are aged between 12 and 18 years of age. Adolescents in the pre-driver age category are over-represented in the number of traffic fatalities and injuries (Wegman \& Aarts, 2006). In this age category adolescents either travel by foot (18\%), by bicycle (52\%), by moped (3\%), or are driven by a parent or a friend (17\%) or use public transportation (9\%; Wegman \& Aarts, 2006).

The overrepresentation of adolescents in road accident statistics has been attributed to situational as well as psychological and developmental factors. For instance, adolescents may have different lifestyles than adults (i.e.; they might stay up late in the weekends) as well as different biorhythms (i.e.; adolescents are more wakeful at night and sleepy in the morning than adults), which may lead to sleep deprivation; they lack the parental supervision they had when they were younger; adolescents may be inclined to be influenced by peers more than adults; and they might be more easily distracted than adults (Shope \& Bingham, 2008). Also their financial situation may play a part - adolescents usually have less money to spend than adults, and might spend the money they have on other 
things than bicycle maintenance (Males, 2009).

Probably one of the most important factors contributing to the increased risk of adolescents in traffic is risk behavior. And because adolescents have the skills to ride a bicycle safely (they have learned it at a very young age) it is assumed that they consciously decide to take risks in traffic. But why would adolescents show more risky behaviors in general and specifically in traffic? First, biological changes may play a role. The adolescent period comes with an onset of hormones which lead to sensitivity for social approval and a tendency to show bravery in the eyes of peers. Moreover, there is an increase in exploratory and rewardseeking activities in adolescence (Dahl, 2008). Furthermore, the early adolescent period is characterized by a decrease in parental supervision or, in other words, an increase in independence (Keating \& Halpern-Felsher, 2008). Thus, adolescents may explore boundaries, they may fail to recognize potentially harmful situations or may actually seek out risky situations, and the chances of encountering these situations increase in adolescence, ultimately leading to a higher risk (Dahl, 2008).

Reyna and Farley (2006) provide a compelling reason why adolescents may seek out situations with potential risks. They state that even though adolescents are capable of rational decision making, they are more willing than adults to explore risky options. Whereas adults are generally risk avoidant, adolescents are likely to weigh the pros and cons of any given situation. Because traffic is objectively quite safe and because adolescents typically prefer short-term benefits over long-term benefits, the pros will often outweigh the cons (Reyna \& Farley, 2006).

Keating and Halpern-Felsher (2008) stress that developmental factors are the most relevant and that expertise only comes with experience and practice. They state that there is no evidence that young drivers underestimate risks more than adult drivers. Reyna and Farley (2006) also found that adolescents, despite conventional wisdom, do feel vulnerable and generally overestimate risks. Indeed, after the age of 14, it can be assumed that there are no differences between teens and adults concerning the perception of risk (Steinberg, 2004). Besides, risky behavior is often not punished, but rather perceived as advantageous (Reason, Manstead, Stradling, Baxter, \& Campbell, 1990). Risky behaviors are hence likely to become a habitual part of one's traffic participation style. It is therefore important to promote risk-avoiding behavior before people start driving cars. However, in order to change risky behavior, a better understanding of the social-cognitive determinants of adolescent road use behaviors is needed.

The best way to find out which behaviors are risky and cause the increased risk of adolescents in traffic is by examining accident data. Usually, accidents 


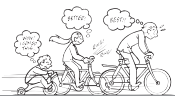

are reported by those involved or the police. This is mainly done for insurance purposes, but the collective data is a treasure for accident research. Compared with car accidents, however, there is hardly any epidemiological data available on specific behaviors causing adolescent traffic injuries, due to a chronic underreporting of accidents when bicycles or scooters are involved (Reason, Manstead, Stradling, Baxter, \& Campbell, 1990). This underreporting is in part due to the lack of insurance claims for bicycles and scooters, but mainly because up till now, there was no apparent need for it. With increasing understanding of the importance of adolescent risk research should come more demand for better data.

Another method of measuring behavior would be to go out in the field, observe behaviors and score the amount of times they occur. Since this is a costly, time-consuming, and inefficient method it is rarely used. Rather, self-report questionnaires are most often used. Participants are for instance to indicate how many times in the last week, month, or year they performed a specific behavior and whether or not they were previously involved in a traffic accident. Even though answers will probably deviate from the objective truth (Neisser \& Harsch, 1992), self-reported behaviors have been shown to correlate strongly with observed behaviors and are therefore considered useful as a means to measure of behavior (Mook, 2001).

When investigating (risky) traffic behavior and its potential determinants, it is important that statistical analysis is supported by evidence and theory. Failing to do so may lead to a situation where a whole series of aspects is found to be associated with the (risky) behavior without really knowing which factors are to be seen as direct or indirect determinants of behavior. Even though identification of socio-demographic, personality-related and situational determinants of adolescent risk taking is useful for targeting interventions, variables like these are not modifiable. Sex, age, or weather conditions are not subject to controlled change. Therefore, attention should be paid to determinants that allow policy makers and program developers to influence behavior (Ouimet et al., 2008). According to Leventhal and Mora (2008), educational interventions that focus on remote goals while ignoring more proximal goals are usually ineffective for behavioral change.

The questionnaire used to measure adolescent risky cycling behavior in the studies described in this dissertation was developed by the Institute for Road Safety Research (SWOV). The original questionnaire actually contained 42 questions regarding risky moped riding, 22 questions regarding risky cycling, and 12 questions regarding pedestrians. According to the developers, the items in the 
questionnaire were designed in accordance with Reason's (1990) subdivision of erroneous behaviors into (conscious) violations, (unconscious) slips and lapses, and (conscious) mistakes. In this subdivision, violations are defined as intentional deviations of what is considered safe. Slips and lapses are errors of the mind, mainly regarding attention. Mistakes are deliberate actions with unintended outcomes.

\section{Intervention mapping}

The relatively large number of fatalities of 12-17 year olds highlights the need for traffic safety programs in secondary schools to promote safe bicycle riding (DVS, 2008; Wegman \& Aarts, 2006). Furthermore, because adolescents are a major risk group when it comes to traffic accidents, and because school is mandatory, adolescents are the ideal target for health education programs.

In order to decrease the risk many traffic education programs have been adopted. Interventions to promote safer bicycle riding in adolescents should start with an assessment aiming to identify specific behaviors contributing to the health and safety problem at hand. Later, social-cognitive determinants of those behaviors should be identified and methods for change selected and integrated into a program, anticipating implementation and evaluation (for a detailed outline of theory- and evidence-based intervention development, see Bartholomew, Parcel, Kok, \& Gottlieb, 2006; Bartholomew, Parcel, Kok, Gottlieb, \& Fernández, 2011).

The value of theory- and evidence-based development and evaluation of educational interventions has been described in detail by various researchers in the health psychology domain (Bartholomew et al., 2006; Fishbein \& Cappella, 2006; Green \& Kreuter, 2005; Michie \& Abraham, 2004; Schaalma, Abraham, Gillmore, \& Kok, 2004). For example, Bartholomew and colleagues developed the Intervention Mapping protocol, a planning framework for the development and evaluation of theory- and evidence-based health promotion programs (Bartholomew et al., 2006; Kok, Schaalma, Ruiter, Van Empelen, \& Brug, 2004). In brief, Intervention Mapping requires interventionists to identify intervention change objectives, or change targets, and specify commonly-understood behavior change techniques that have been used to bring about these planned changes. By basing such decisions on previous evidence and documenting the way in which intervention materials are designed interventionists can communicate clearly about intervention content thus facilitating replication and 
subsequent intervention development (Abraham, Kok, Schaalma \& Luszczynska, 2010).

While many possible causes of risky cycling behavior have been identified, a need for a better insight into social-cognitive determinants still exists. Without a decent understanding of the social-cognitive determinants underlying risky cycling behavior, education initiatives focused on behavior change are bound to fail. Accurate insights will lead to proper focal points of interventions, which increase the chance of interventions being successful in improving safer traffic behavior and in reducing accidents.

Many traffic safety interventions have been implemented in the school setting to educate the pre-driver population about traffic safety. However, only a very small number of these education programs have been systematically evaluated. As a result, the effectiveness of school-based traffic safety education is largely unknown. The lack of systematic evaluation is further accompanied by a lack of systematic development of traffic safety education. Either way, only through systematic evaluation is it possible to differentiate the effective and ineffective ingredients of an intervention. The evaluation of a traffic safety education program called Traffic Informers is the main purpose of this dissertation.

\section{The Traffic Informer Program}

Traffic Informers is a traffic safety education program developed to increase awareness among young people about the risks involved in traffic and the consequences of accidents. It aims to do so by showing secondary school students videos of crashes and allowing the students to engage in a discussion with a traffic injury victim (the traffic informer) about the consequences of accidents. According to the program developers, the confrontation and interaction with the traffic injury victim causes a positive effect on young people's traffic behavior. The traffic informer acts as a negative role model, in that students are advised not to do what the traffic informer has done.

The program starts by showing a video in class that consists mostly of short video fragments meant for U.K. television broadcasting. Most of the video fragments were made in cooperation with either the Department of the Environment (DOE) or AXA insurance. In the video fragments, the events prior to an accident, the accident itself, and the consequence are depicted in detail. The dissuasive videos of traffic accidents are not common on Dutch television due to 
their graphic and fear-inducing nature, but are readily available on international video websites (e.g., YouTube).

Following the video, the traffic informer then unravels his/her story in the same fashion as the videos. After a description of life before the accident, he then describes the accident (or what he knows of it) and finishes with the consequences. Afterwards, the class' teacher is asked to lead a discussion between the students and the victim. Students commonly ask questions about subjects they find interesting, for instance about the victim's friendships, relationships, and sex life.

Finally, the teacher and students evaluate the program in class, usually one week after the program. The evaluation report is then sent to the traffic informer program manager. According to the program's website, students claim to change their behavior in traffic, for instance to wear a helmet and to not drink before participating in traffic. See the program's website for more information (in Dutch; www.trafficinformerslimburg.nl).

\section{Fear appeals}

One of the most prevalent aspects of Traffic Informers is the use of confronting materials. Such frightening materials are called fear appeals, defined as a persuasive communication attempting to arouse fear in order to promote precautionary motivation and self-protective action (Rogers, 1983). The use of fear appeals is widespread and popular among health education practices, for instance in anti-smoking and anti-drug abuse campaigns (Witte, 1992; Witte \& Allen, 2000). The central persuasive argument that fuels these health campaigns is clear: vividly show people the negative health consequences of life-endangering behaviors and they will be motivated to moderate their current risk behavior and adopt more safe alternative behaviors.

However, there is a large body of evidence disputing the use of fear arousal to motivate people to change their behavior (De Hoog, Stroebe, \& de Wit, 2005, 2007; Lewis, Watson, \& Tay, 2007; Lewis, Watson, White, \& Tay, 2007; Ruiter, Abraham, \& Kok, 2001; Taubman Ben-Ari, Florian, \& Mikulincer, 2000; Van Wel \& Knobbout, 1998; Witte, 1992; Witte \& Allen, 2000). In fact, there are examples where interventions based on fear arousal yielded defensive responses including avoidance of the health information (Kessels, Ruiter, \& Jansma, 2010), denial of the health risk (Liberman \& Chaiken, 1992), and even increased risk behavior (Taubman Ben-Ari et al., 2000). To counter these defensive processes and promote 
self-protective action, theoretical frameworks of fear appeals have emphasized the use of coping information that provides specific behavioral instructions on how to effectively deal with the health threat (Rippetoe \& Rogers, 1987; Rogers, 1983; Witte, 1992). For instance, when one wants to quit smoking, it would not be sufficient to show a picture of a tar-covered lung. This picture will evoke negative emotions that motivates the quitter to develop defensive responses, for instance to think that the picture does not apply to him. Only when instructions on how to quit effectively are provided, for instance the telephone number of a clinic specialized in smoking cessation, the quitter may be more likely to take appropriate action (i.e., pick up the phone and call the clinic).

\section{Hypothesis and overview}

The main objective of the thesis is to describe and illustrate the current state of affairs regarding traffic education for adolescents. As an example the Traffic Informer program that is currently used in Limburg is evaluated. Before the evaluation could take place, more information about measuring risky adolescent behavior in traffic was needed. Following the literature on adolescent risk behavior and the effectiveness of fear appeals, it is hypothesized that the traffic informer program might be capable of raising awareness about the consequences of traffic accidents. However, the probability that students following the program will actually change their risk behavior accordingly is small.

In chapter 2, the factor structure of a self-report questionnaire measuring adolescent risky cycling behavior (ACBQ) is determined. The ACBQ is a questionnaire that contains all kinds of risky behaviors adolescents perform in traffic. Research on risky automobile driving revealed that certain types of unsafe behavior may have the same underlying specification. According to Reason (1990) there are three distinct types of unsafe behavior that may lead to accidents, namely errors (slips/lapses), mistakes, and violations. This distinction has been found in complex behavior, like driving a car, but has not yet been studied in cycling behavior. However, different risky cycling behaviors may just as well have different underlying factors. In this chapter factor analysis is used to determine these factors.

In chapter 3 the social-cognitive correlates of risky adolescent cycling behavior are presented. Most safety education programs to date focus on accident statistics and risk perceptions. In this chapter it is proposed to investigate the social-cognitive correlates of risky cycling behaviors prior to the development 
of safety education programs.

Chapter 4 presents the actual evaluation of the Traffic Informer program. Traffic Informers is a large program targeting secondary school students. Students and teachers alike praise the program for its success. The effect the program seemingly has on students is indeed hopeful. However, success of an education program can be measured. Thus, using a quasi-experimental design (pre-test post-test) students who attended the Traffic Informer program (experimental group) were compared with students who did not (yet) attend the program (control group) on attitudes, intentions, and behavior in traffic.

In chapter 5 we describe a study conducted among 30 adolescent and 30 adult males, in which we aimed to provide evidence for an often quoted (but rarely researched) assumption in risky adolescent behavior research, namely that adolescents are slower than adults when responding to threats.

Finally, in chapter 6 , the results of the foregoing chapters will be discussed and guidelines for future research and intervention development will be provided. 




\title{
Chapter 2
}

\author{
Measuring risky \\ adolescent cycling \\ behavior
}

This chapter was previously published as: Feenstra, H., Ruiter, R.A.C., Schepers, J., Peters, G.J., \& Kok, G. (2011). Measuring risky adolescent cycling behavior. International Journal of Injury Control and Safety Promotion, iFirst art, 1-7. 
The Netherlands are top ranked among other European countries when it comes to the use of bicycles. Especially for secondary school students (ages $12-17$ years) the bicycle is an important mode of transport. Students use the bicycle for as much as $52 \%$ of all their journeys (Wegman \& Aarts, 2006). Bicycle use entails relatively high safety and health risks (DVS, 2008; SWOV, 2006). Although the number of registered cyclist deaths has been halved during the 1987- 2005 period (i.e., from 311 to 151 per year), and the annual number of in-patients also decreased (i.e., from 3093 in 1987 to 2186 in 2005), the proportion of cyclist fatalities in the total number of fatalities is relatively large (SWOV, 2006). In 2006 the proportion of cyclist fatalities was $23 \%$ of all traffic fatalities and cyclist injuries accounted for $43 \%$ of all traffic injuries, whereas on average only $14 \%$ of all travel kilometers is done by bicycles (DVS, 2008; Lynam et al., 2005). Alongside cyclists aged 60 years and older, the 12-17 year olds have a relatively large number of fatalities as well, which highlights the need for traffic safety programs in secondary schools to promote safe bicycle riding (DVS, 2008; Wegman \& Aarts, 2006).

Interventions to promote safer bicycle riding in adolescents should start with an assessment aiming to identify specific behaviors contributing to the health and safety problem at hand. Later, determinants of those behaviors should be identified and methods for change selected and integrated into a program, anticipating implementation and evaluation (for a detailed outline of theoryand evidence-based intervention development, see Bartholomew, Parcel, Kok, \& Gottlieb, 2006; Bartholomew, Parcel, Kok, Gottlieb, \& Fernández, 2011).

The Dutch national road safety research institute (SWOV) developed a questionnaire that measures risky bicycle riding behavior (Twisk, Vlakveld, \& Commandeur, 2007), further referred to as the Adolescent Cycling Behavior Questionnaire $(A C B Q)$. The $A C B Q$ was modeled on the Driver Behavior Questionnaire (DBQ), although there was not a close parallel between the specific items included. The DBQ is employed frequently in the road safety literature and makes a distinction between errors and violations that has proven useful (Reason, Manstead, Stradling, Baxter, \& Campbell, 1990; Reason, Manstead, Stradling, Parker, \& Baxter, 1991). Even though the ACBQ-items are not a reflection of the items in the frequently used $D B Q$, the $A C B Q$ also distinguishes errors from violations.

Violations are "deliberate deviations from those practices believed necessary to maintain a safe operation of a potentially hazardous system" (Reason et al., 1990, p. 1316), whereas errors are defined as "the failure of planned actions to achieve their intended consequences" (p.1315). Errors can be further sub-divided 


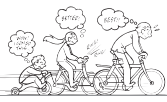

into mistakes and slips or lapses. A mistake is "the departure of planned actions from some satisfactory path towards a desired goal" (p. 1315); for example taking a turn when trying to avoid a traffic jam and finding out that you are entering a one-way street from the wrong side. Slips or lapses are "the unwitting deviation of action from intention" (p. 1315); for instance attention and memory failures (Reason et al., 1990). Reason and colleagues (1990) suggested that violations, not errors, would predict accident involvement. For instance, Parker, Reason, Manstead and Stradling (1995) and Parker, West, Stradling and Manstead (1995) found that car drivers reporting a higher frequency of violations are more likely to be involved in accidents than car drivers reporting a lower frequency of violations. However, a relationship between errors and accidents has also been found (Davey, Freeman, \& Wishart, 2007; Mesken, Lajunen, \& Summala, 2002). Finding evidence that this distinction is valid for cyclists could provide suggestions to shift the focus of traffic safety programs and possibly improve their effectiveness.

Although the $A C B Q$ has been used in a study evaluating traffic safety education programs in the Netherlands (Twisk et al., 2007), no scientific publications are available on its psychometric properties. Furthermore, there is no systematic research on the relation between measures of risky cycling behavior, like the $A C B Q$, and actual injuries from traffic accidents.

In the present study we focus on measuring unsafe cycling behavior using the $A C B Q$. The aim of this study is to identify the parametric properties of the $A C B Q$, consider its relationships with injuries, and to investigate whether the postulated distinction between violations and errors emerges in a large sample of adolescent cyclists.

\section{Methods}

\section{Study Setting and Procedure}

Self-report measures of risky bicycle behavior using the ACBQ were administered to students aged 13 to 18 from eight schools one week before the start of a traffic safety education program. Students from three levels of education (i.e., lower and higher general secondary education, and pre-university college) were asked to participate in the study. The boards of directors of the schools agreed to cooperate in this study. Participation was voluntary with no repercussions when a student refused to participate. The questionnaires were handed out by a teacher during class and participants needed about twenty minutes to fill them out. The Ethics Committee Psychology of Maastricht University approved the study. 


\section{Participants}

A total of 2500 questionnaires were distributed of which 2033 questionnaires were returned filled out. Most participants $(N=1749)$ were identified as cyclists on the basis that they reported riding a bike 'more than 3 times a week'. From these 1749 bicycle riders (52.6\% girls), 155 girls and 180 boys attended lower general secondary education, whereas 707 girls and 619 boys attended higher general secondary education, pre-university college, or a combination. Of 48 girls and 30 boys the data were inconclusive about their education level, but these 78 participants were retained for analysis. The age of the participants ranged from 13 to 18 years. The mean age for girls was 15.0 years $(S D=0.81)$, and 15.1 years for boys $(S D=0.85)$.

\section{Measures}

Cycling behavior. Self-reported risky cycling behaviors were assessed with the ACBQ (Feenstra, Ruiter, \& Kok, 2010; Twisk et al., 2007), which consists of 22 items. Participants were asked how often they performed different kinds of dangerous cycling behavior in the past month. Scores on these items ranged from $1=$ never to $6=$ always. The cycling behavior items are shown in Table 1.

(Near) Accident involvement. Because none of the participants in our study had been involved in an accident during the 3-month study period we were not able to relate the $A C B Q$ scores to accident involvement. Instead we related the ACBQ scores to a self-report measure of past accident involvement. Three items assessed the level of accident involvement. The first item: "In the past two years, have you had an accident so severe, that you had to see a doctor or were taken to a hospital?" ( 1 = no, 2 =yes, but no harm done $1,3=$ yes, had to see a doctor, $4=$ yes, had to stay in the hospital) measures accident severity; the second item: "In the past two years, have you had an accident whereby your bike was damaged?" (1 $=$ no, 2 = once, $3=$ twice, $4=$ more often) measures accident frequency. The third item: "How often did you almost have an accident?" (1 = practically never, 2 = a couple of times per year, 3 = practically every month, and 4 = practically every week) was taken as a measure of near-miss frequency. Even though it has been shown in car drivers that most near-misses in the past year are forgotten (Chapman \& Underwood, 2000), near accidents have been found to correlate with risky driving behavior (Iverson \& Rundmo, 2002; Karlberg, Undén, Elofsson, \& Krakau, 1998).

\section{Statistical Analyses}

Missing scores $(<1 \%)$ were replaced with the average score of the sample on the specific items to retain all bicycle riders in the analyses. To identify the underlying

1) Response option 2 (yes, but no harm done) was recoded to 1 (no) to make more sense as a response to the question. 
factor structure of the ACBQ the data set was randomly split into two almost equally large parts: a training data set $(N=875)$ and a test data set $(N=874)$. The former is used to extract a factor solution, which can then be fitted to the latter in order to assess to what degree the extracted factor solution may still hold true in an independent sample of data. This prevents interpreting highly sample-specific results.

In order to extract a factor solution from the training data set, a parallel analysis (O'Connor, 2000) was employed (number of replications $=100$ ). The resulting solution was subjected to an Oblimin rotation to yield a simple structure. For those items with an absolute loading value greater than 0.30 a confirmatory factor analysis (CFA) was used to obtain maximum likelihood estimates ${ }^{2}$, while all other items were constrained to be zero. By means of a specification search that is guided by modification indices (Long, 1983), CFA may allow for the identification of further adjustments to the model that improve its fit. Modifications were based on the Tucker Lewis Index (TLI) and the Standardized Root Mean Squared Residual (SRMR). For these indices, values larger than 0.90 and smaller than 0.05, respectively, have found to be indicative for good model fit (see e.g., Hu \& Bentler, 1999).

Next, we tested (again using CFA) whether the model retrieved from the training data set also fitted the independent test data set. Lack of fit would suggest that at least some of the relations that are implied by the final model are highly sample-specific. Conversely, good fit indicates generalizability, extending the conclusions offered by applications of factor analysis that only consider a single sample.

Finally, reliability analyses (Cronbach's alpha) were conducted to confirm the internal consistency of scores of items that load on a single factor. To establish the relationship between the identified factors and accident involvement and the number of near accidents, correlation coefficients were calculated and linear multiple regression analysis was conducted. Only those factors were included as predictor in the regression analyses that showed significant bivariate relationships with the outcome measure. Furthermore, Variance Inflation Factor (VIF; the factor by which variance is increased due to multicollinearity) scores were calculated to check for multicollinearity among the factors. VIF scores higher than 10 indicate multicollinearity, but scores higher than 2.5 may already be a cause for concern. The analyses controlled for age and gender differences. Finally, independent samples t-tests were used to test whether gender and age of the participants influenced the scores on the identified factors. 


\section{Results}

\section{Factor analysis}

The parallel analysis indicated that a three factor solution was most appropriate. After identifying all loadings with an absolute value greater than 0.30 , a confirmatory factor analysis (CFA) was conducted. Modification indices suggested that three items loaded on more than one factor: 'Using a cell phone whilst cycling' not only loaded on factor 2, but on factor 3 as well; 'Ride when having drunk alcohol' loaded on both factor 3 and factor 2; and 'Cycling close to someone else, handlebars touching' not only loaded on factor 1, but also on factor 2 .

Finally, a residual covariation between two items ('forget to signal when changing directions' and 'forget to look behind when turning left') was suggested. CFA was repeated until no more modifications were suggested. The final model (see Table 1) was found to fit the training data set well, as suggested by a large value for the Tucker Lewis Index $(T L I=.92)$ and a small value for the Standardized Root Mean Squared Residual (SRMR $=.04)$.

To summarize, the CFA yielded three factors (see Table 1). The first factor contains behaviors that can easily be classified as mistakes and slips, and can therefore be named 'errors.' The second factor that was found contains behavioral violations that are common in traffic, henceforth named 'common violations'. The final factor also contains violations, however these violations may either not occur everyday (for instance the use of drugs) or need another party (a moped or someone on the phone) this factor is named 'exceptional violations'.

Finally, we tested whether the model also fitted the independent test data set. The CFA of the independent test data yielded indices suggesting good model fit $\left(\mathrm{X}^{2}=615.45, d f=202, p<.001, \mathrm{TLI}=.94, \mathrm{SRMR}=.04, \mathrm{CN}=336\right)$.

\section{Reliability}

Because the CFA of the independent test data suggested good model fit, reliability analyses were performed on the items loading on one of the three factors. The reliability scores were acceptable for all three factors (see Table 1). Factor averages were computed per participant. An ANOVA on these factor means with factor as within-subjects variable showed significant differences between factors. Multiple comparisons with bonferoni correction revealed that across participants 'common violations' were reported more often than 'errors' and 'exceptional violations' ( $p$ 's $<.01)$. 
Table 1. Factor loadings, means, and standard deviations of ACBQ items in order of reported prevalence.

\begin{tabular}{|c|c|c|c|c|c|}
\hline \multirow{2}{*}{$\begin{array}{l}\text { Items } \\
\text { How often in the past month did you... } \\
(1=\text { never, } 6=\text { always })\end{array}$} & \multicolumn{3}{|c|}{ Factors } & \multirow[b]{2}{*}{ M } & \multirow[b]{2}{*}{$S D$} \\
\hline & Errors & $\begin{array}{l}\text { Common } \\
\text { violations }\end{array}$ & $\begin{array}{l}\text { Exceptional } \\
\text { violations }\end{array}$ & & \\
\hline Forget to signal when changing directions & & .77 & & 3.29 & 1.61 \\
\hline Ride in threes & & .70 & & 2.90 & 1.33 \\
\hline Ride on the sidewalk & & .57 & & 2.64 & 1.20 \\
\hline Use a cell phone whilst cycling & & .47 & .47 & 2.53 & 1.44 \\
\hline Forget to look behind when turning left & & .59 & & 2.40 & 1.37 \\
\hline Cycle when it was slippery and you could fall easily & .36 & .31 & & 2.26 & 1.30 \\
\hline Ride at night without a working head- or tail light & & .49 & & 2.17 & 1.36 \\
\hline Ignore a red traffic light & & .44 & & 2.16 & 1.20 \\
\hline $\begin{array}{l}\text { Ride so close to someone else, that the handlebars } \\
\text { touched and you almost fell }\end{array}$ & .44 & .44 & & 2.07 & 1.04 \\
\hline $\begin{array}{l}\text { Swerve around crossing pedestrians on a zebra- } \\
\text { crossing }\end{array}$ & & .37 & & 1.94 & 1.17 \\
\hline Not see a car coming from a side street & .58 & & & 1.92 & .94 \\
\hline $\begin{array}{l}\text { Have to brake hard, because a car approached faster } \\
\text { than you anticipated }\end{array}$ & .59 & & & 1.88 & .90 \\
\hline $\begin{array}{l}\text { Notice you ought to ride on the bike-way instead of } \\
\text { on the road }\end{array}$ & .46 & & & 1.70 & 1.13 \\
\hline $\begin{array}{l}\text { Stop on the right side of a truck that wanted to turn } \\
\text { left, instead of waiting behind it }\end{array}$ & .40 & & & 1.69 & .91 \\
\hline $\begin{array}{l}\text { Brake (too) late, because you were on someone } \\
\text { else's bike and the brakes worked different }\end{array}$ & & & .75 & 1.69 & 1.07 \\
\hline $\begin{array}{l}\text { Feel uncertain about who had the right of way on a } \\
\text { traffic circle }\end{array}$ & .59 & & & 1.67 & 1.23 \\
\hline Ride when having drunk alcohol & .52 & & & 1.54 & .98 \\
\hline $\begin{array}{l}\text { Notice you entered a one-way street on the wrong } \\
\text { side }\end{array}$ & .49 & & & 1.52 & .95 \\
\hline $\begin{array}{l}\text { Have to swerve in order not to get run over by a bus } \\
\text { or truck turning right }\end{array}$ & .67 & & & 1.42 & .86 \\
\hline Get pushed or pulled by a moped rider & & & .71 & 1.41 & .91 \\
\hline Almost hit a crossing pedestrian when turning right & .66 & & & 1.33 & .65 \\
\hline $\begin{array}{l}\text { Ride a bicycle while under the influence of mari- } \\
\text { juana or other drugs }\end{array}$ & & & .73 & 1.18 & .72 \\
\hline Cronbach's alpha (a) & .82 & .82 & .71 & & \\
\hline Variance explained (\%) & & & & 45.77 & \\
\hline
\end{tabular}

$N=1749$; factor loadings $<.30$ have been omitted

for clarity. 


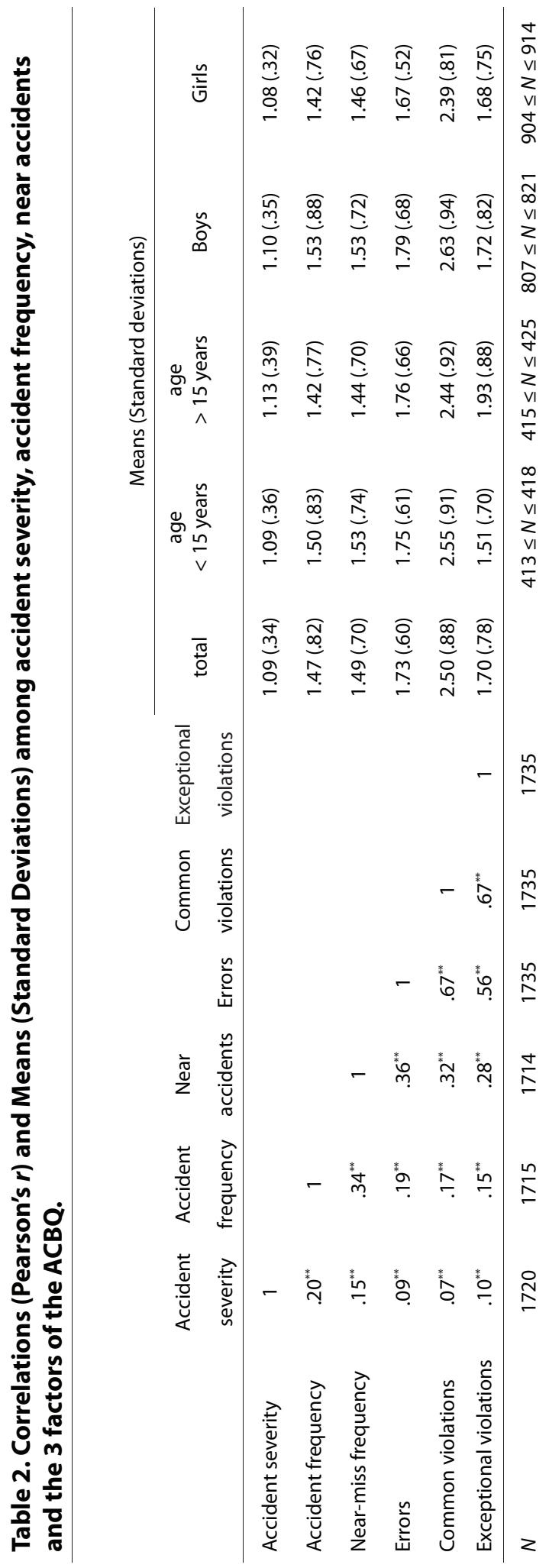


Relation with demographic characteristics and near accidents

Table 2 shows the relationships between errors, common and exceptional violations, accident involvement, near-miss frequency, gender, and age. Independent sample t-tests reveal that, in general, boys report more errors, $t(1747)=4.09, p<.001$, Cohen's $d=.20$, and common violations, $t(1747)=5.73$, $p<.001$, Cohen's $d=.27$, than girls. On exceptional violations no significant difference was found between boys and girls, $t(1747)=1.07, n s$, Cohen's $d=.05$.

Comparing younger participants (age $<15$ years; $M_{\text {age }}=13.9 \mathrm{yrs}, S D=.26 ; n=$ 420) with older participants (age $>15 \mathrm{yrs} ; M_{\text {age }}=16.2 \mathrm{yrs}, S D=.36 ; n=435$ ) showed no difference between participants under fifteen and over fifteen in the amount of reported errors, $t(853)=.33, n s$, Cohen's $d=.02$, and common violations, $t(853)$ $=1.77, p=.08$, Cohen's $d=.12$. A significant difference was found on reported exceptional violations, $t(853)=7.80, p<.001$, Cohen's $d=.68$, with participants over fifteen reporting more exceptional violations than participants under fifteen.

Correlation analyses showed that all three types of risk behavior were significantly related to accident severity, accident frequency, and near-miss frequency (all $p$ 's $<.05$ ) with the relationships being positive but small. Regression analyses were conducted separately for accident severity, accident frequency, and near-miss frequency as dependent variables, and the three factors and age and gender as independent variables. It appears from table 2 that the associations between errors, common violations, and exceptional violations are moderately high, which could disrupt the regression models. However, with VIF scores not exceeding 2.37, multicollinearity is not of concern here.

The regression analyses (Table 3 ) show that the three factors of the ACBQ are only able to explain $1 \%$ of the variance in accident severity, $4 \%$ of the variance in accident frequency, but $15 \%$ of the variance in past near accidents. Exceptional violations appear to be related to accident severity and near accidents; errors appear to be related to accident frequency and near accidents, whereas common violations appear to be related only to near-miss frequency ${ }^{3}$. 
Table 3. Summary of linear multiple regression for accident severity, accident frequency, and near accidents.

\begin{tabular}{lccc}
\hline & Accident severity & Accident frequency & Near accidents \\
\hline \multirow{nyyy}{*}{ Sex $(1=$ female, $2=$ male $)$} & $B$ & $B$ & $B$ \\
Age & & $.05^{*}$ & .02 \\
Errors & & & $-07^{* *}$ \\
Common violations & .06 & $.13^{* * *}$ & $.26^{* *}$ \\
Exceptional violations & -.02 & .05 & $.09^{* *}$ \\
$R^{2}$ & $.08^{*}$ & .04 & $.09^{* *}$ \\
& .01 & .04 & .15
\end{tabular}

$F \quad F(3,1716)=4.03^{* *} \quad F(3,1710)=19.37^{* *} \quad F(3,1708)=59.90^{* * *}$

" Regression coefficient is significant at the .05 level (2-tailed), "* Regression coefficient is significant at the .01 level (2-tailed).

\section{Discussion}

The objectives of this article were to identify the parametric properties of a risky cycling behavior questionnaire aimed at adolescents (ACBQ), its relationships with injuries, and to investigate whether a distinction between violations and errors was to be found. Factor analysis revealed a three-factor structure underlying the questionnaire; these three underlying factors were identified as errors, common violations, and exceptional violations. The same structure was found in an independent data set, indicating good generalizability of the model, suggesting that the $A C B Q$ is useful in measuring risky cycling behavior of adolescents.

Correlation analysis showed small positive relationships between the three underlying factors on the one hand and accident severity, accident frequency, and near-miss frequency on the other hand. However, there is no support for the original suggestion by Reason and colleagues (1990) that violations, not errors, predict accident involvement. Rather, from the regression analyses it appears that errors may influence accident frequency, and that accident severity is influenced by exceptional violations, although their respective predictive value is small. Nearmiss frequency can be predicted by errors and common violations. It thus appears that for cycling behavior a sub-division of errors is unnecessary, and that slips and mistakes fall into the same category. It does however seem to make sense to divide violations into two categories; much like research has shown that it made sense to add a category of aggressive violations to the DBQ (Chapman, Roberts, \& 
Underwood, 2000; Lawton, Parker, Manstead, \& Stradling, 1997).

T-tests revealed that boys report more errors and common violations than girls, but concerning exceptional violations boys and girls report similar frequencies. This result confirms similar findings in studies that used the DBQ (Özkan, Lajunen, \& Summala, 2006; Verschuur \& Hurts, 2008), in that men report more errors and violations than female drivers. However, no difference between boys and girls in accident frequency was found, contradicting accident statistics that report more injuries among girls (Lynam et al., 2005).

No age differences were found on reported errors and common violations. These appear to be made by teens of all ages (between 13 and 18) in the same amount. With increasing age, however, exceptional violations are more often reported (e.g., drinking, drugs, and being pushed or pulled by a moped), All in all, judging from the present data, risky behaviors are not performed often by adolescents ranging from 13 to 18 years of age.

There are some limitations to this study. First of all, the measures of accident severity, accident frequency, and near-miss frequency were assessed using self-reports. Participants were to recall from the past two years whether or not they had accidents or near accidents, how many accidents and near accidents, and how severe they were. Drivers' memories of accidents and near accidents are however poor (Chapman \& Groeger, 2004; Chapman \& Underwood, 2000). When studying accident and near accident recall, Chapman and Underwood (2000) found that after a delay of just two weeks about $80 \%$ of the near accidents are already forgotten. Actual accidents were least likely to be forgotten if the participant was to blame. It may thus very well be the case that accident and near-miss frequency in the present study is underreported.

Secondly, another shortcoming of this study is that cross-sectional data were used. The relationships considered in this study are between retrospectively recalled accidents and currently measured behavior. This order is more likely to reflect an influence of accident experience on behavior than an influence of behavior on accident experience.

Finally, it should be noted that all items making up the ACBQ are negative/ risky behaviors. Combining positive and negatively worded items may safeguard against defensive reactions of the participants. The ACBQ might be improved by including items on safe behaviors or at least positively worded items instead of only negative (risky) items. Similar suggestions were made regarding the DBQ (Özkan \& Lajunen, 2005).

The ACBQ appears to be a promising instrument for researching adolescent risky cycling behavior. Prospective studies should demonstrate the validity of the 
ACBQ in predicting accident involvement. Furthermore, in order to systematically develop theory- and evidence-based safety promotion interventions, socialcognitive determinants of adolescent cycling behaviors need to be identified. Finally, the results of this and future studies should be related to adolescent risk perception. 




\section{Chapter 3}

\section{Social-cognitive correlates of risky adolescent cycling behavior}

This chapter was previously published as: Feenstra, H., Ruiter, R.A.C., 
The present study was set up to investigate the social-cognitive correlates of risky cycling behaviors of adolescents. Bicycles are a common means of transportation for adolescents in the Netherlands, as well as in other European countries.

However, their use also entails high safety and health risks as observed in accident statistics. In 2007, over 3000 adolescents (age 16 -24) were hospitalized and 169 died in traffic accidents (DVS, 2008). In order to decrease the risk many traffic education programs have been adopted. However, most programs lack a decent empirical basis. These programs are based on accident statistics only and not on social psychological determinants of teenage cycling behavior. An insight into the social psychological determinants of teenage cycling behavior is important when behavior change is the aim of the program (Bartholomew, Parcel, Kok, \& Gottlieb, 2006). Interventions to promote safer cycling in adolescents should start with an assessment aiming to identify specific behaviors contributing to the health and safety problem at hand and their social-cognitive determinants. Following the formulation of program objectives, methods for change are selected that target the identified social-cognitive determinants. These methods are then translated in specific strategies that fit the intervention context and integrated into a comprehensive intervention program while anticipating program implementation and evaluation (Bartholomew et al., 2006; Kok, Schaalma, Ruiter, Van Empelen, \& Brug, 2004). The present study aimed to identify relevant socialcognitive correlates of risky cycling behavior in adolescents to inform future intervention programs.

Many explanations have been put forward explaining why adolescents show more risky behaviors in general and specifically in traffic (for overviews, see Dahl, 2008; Keating \& Halpern-Felsher, 2008; Shope \& Bingham, 2008; Reyna $\&$ Farley, 2006). For instance, when children reach adolescence, this coincides with an increase in independence. Because adolescents may explore boundaries, may fail to recognize potentially harmful situations or may actually seek out risky situations, chances of encountering these situations increase, which would not happen (or happen less) under parental supervision (Dahl, 2008). The early adolescent period is characterized by a decrease in parental supervision (Keating \& Halpern-Felsher, 2008). Biologically, the adolescent period comes with an onset of hormones which lead to sensitivity for social approval and a tendency to show bravery in the eyes of peers. Moreover, there is an increase in exploratory and reward-seeking activities in adolescence (Dahl, 2008). Besides, because adolescents do have the skills to ride a bicycle safely it is often assumed that it is the adolescents' conscious decision to take risks in traffic. But is that really the case, or are there other purposes for their behavior, like 'being cool' (Shope \& 
Bingham, 2008)?

Reyna and Farley (2006) provide an overview of explanations why adolescents may seek out situations with potential risks. For instance, they state that adolescents are capable of rational decision making but they are also, more than adults, willing to explore risky options. Whereas adults are generally risk avoidant, adolescents are likely to weigh the pros and cons of any given situation. Often the pros will outweigh the cons, because traffic is objectively quite safe and adolescents typically prefer short-term benefits over long-term benefits (Reyna \& Farley, 2006).

There is a good chance risky behavior of car drivers has its origin in the driver's younger years. Reason and colleagues suggest that people learn to act dangerously in traffic because risky behavior is often not punished, but rather perceived as advantageous (Reason, Manstead, Stradling, Baxter, \& Campbell, 1990). Thus risky behaviors are likely to become a habitual part of one's driving style. It is therefore important to promote risk-avoiding behavior before people start driving cars and preferably during early adolescence.

Shope and Bingham (2008) list a series of possible determinants explaining why young drivers run more risk than adult drivers: characteristics of the behavior (i.e., staying up late in the weekends, which leads to sleep deprivation), abilities (i.e., lack of expertise), developmental factors (i.e., brain development), behavioral factors (i.e., aggression), personality (i.e., hostility), demographics (i.e., less parental supervision), social environmental factors (i.e., peers), and physical environment (i.e., distractions). Males (2009) states that the financial situation of adolescents may play a part - adolescents usually have less money to spend than adults, and consequently are forced to buy cars of lesser quality. Keating and Halpern-Felsher (2008) suggest that developmental factors are the most relevant and that expertise comes with experience and practice. They state that there is no evidence that young drivers underestimate risks more than adult drivers. Reyna and Farley (2006) also stress that adolescents, despite conventional wisdom, do feel vulnerable and generally overestimate risks. Indeed, after the age of 14, it can be assumed that there are no differences between teens and adults concerning the perception of risk (Steinberg, 2004). Traffic education should therefore not focus on accuracy of risk perceptions, or on deliberately weighing pros and cons, but should promote risk-avoiding behaviors instead (Reyna \& Farley, 2006). In addition, all these authors urge for a better understanding of the social-cognitive determinants of adolescent road use behaviors, since through those determinants behavior might be changed.

In the present study we focus on risky adolescent cycling behavior in the 
Netherlands from a social psychological perspective. The goal of this study is to analyze the relation between risky behavior and relevant social-cognitive determinants. The determinants measured in this study were selected based on current theoretical insights (Bartholomew, 2006), specific social cognition models of human risk behavior, in particular Theory of Planned Behavior (Ajzen, 1991; Godin \& Kok, 1996) and on expected associations with safe or unsafe cycling: riskperceptions, attitudes, responsibility, experience with accidents, and self-efficacy.

While many causes of risky cycling behavior are known, a need for a better insight into social cognitive determinants still exists. Without a decent understanding of the social cognitive determinants underlying risky cycling behavior, education initiatives focused on behavior change are bound to fail. Accurate insights will lead to proper focal points of interventions, which increase the chance of interventions being successful in improving safer traffic behavior and reducing accidents. This study aims to contribute to a better insight into these social cognitive determinants.

\section{Methods}

\section{Participants and Procedure}

Data were collected from 1749 secondary school students aged 13 to 18 years from seven schools in the province of Limburg, the Netherlands, who were identified as bicyclists (i.e., they indicated they ride their bike more than three times a week). The study was approved by the Ethical Committee Psychology of the School of Psychology and Neuroscience, Maastricht University. Students from three levels of secondary education participated in the study (i.e., lower and higher general secondary education, and pre-university college). They filled out a questionnaire with self-report measures of risky cycling behavior and items measuring attitude, self-efficacy, risk judgments, intentions, and personal experiences. It took about twenty minutes to fill out the questionnaire. Questionnaires were handed out in class, where a teacher supervised the process and, if necessary, clarified any problems regarding the contents of the questionnaire.

Participants who failed to enter their name, age, sex, or any of the key measures were excluded from the analysis $(n=303)$, which resulted in a final sample of 1446 students. T-tests revealed no significant differences between excluded and included participants on age, sex, and the outcome of intention and behavior ( $p$ 's > .05). In the final sample 291 students (141 girls) attended lower 
general secondary education ( $20.1 \%$ of total), 569 students (302 girls) attended higher general secondary education (39.4\% of total), and 277 girls and 247 boys attended pre-university college (36.2\% of total). The level of education of 41 girls and 21 boys could not be established for certain (4.3\% of total), but they were retained for analysis. Mean age was $15.0(S D=.79)$ for girls as well as for boys (SD $=.83)$.

\section{Measures}

For each measure, scores on separate items that showed sufficient internal consistency (Cronbach's alpha [a] > .60) were averaged into one single index (unless otherwise indicated). Higher scores reflect a stronger presence of the concerned variable.

Risky cycling intention. Intention to perform dangerous cycling behavior was measured by a combination of three questions reflecting Reason and colleagues' (1990) subdivision of errors: The first question "How often in the next month do you intend to break traffic rules?" pertains to violations (a deviation from what is deemed safe), the second "How often in the next month do you expect to get in a potentially harmful situation because of an error you make in traffic?" pertains to mistakes (conscious but wrong decisions), and the third "How often in the next month do you expect to break traffic rules unknowingly?" to slips and lapses (unconscious errors). Scores ranged from $1=$ never to $6=$ always $(a=.60)$.

Risky cycling behavior. The Dutch Institute for Traffic Safety Research (SWOV) has developed a questionnaire that measures risky bicycle behavior (Twisk, Vlakveld, \& Commandeur, 2007). Participants were asked to state the number of times they performed 22 different kinds of intended or unintended dangerous cycling behavior in the past month (e.g., "Riding a bike when under the influence of alcohol/marijuana", "Using a cell phone whilst cycling", "Forgetting to signal when changing directions", and "Riding at night without working head/tail light"). Scores on these items ranged from $1=$ never to $6=$ always $(a=.88)$.

Self-efficacy. Self-efficacy concerning traffic skills was measured using a comparison to other cyclists of similar age and sex regarding five issues: Controlling your bicycle, applying traffic rules, traffic situation insight, ability to withstand temptations to take risks, and ability to withstand peer pressure. Response options ranged from $1=$ much worse to $5=$ much better $(\alpha=.66)$.

Risk comparison. Participants were asked about their comparative risk to have a traffic accident with a single item: "Compared to other bicycle riders of my age and sex my risk of having a traffic accident is... ". The response options ranged from $1=$ much smaller to $5=$ much higher. 
Attitude towards traffic violations. Attitude toward violating traffic rules was measured using five items, e.g., "It should be up to me whether I obey the traffic rules or not", "With no traffic in sight, stopping in front of a red light makes no sense". Response options ranged from $1=$ totally disagree to $5=$ totally agree $(\alpha=.67)$.

Attitude towards alcohol use in traffic. Attitude towards drunk driving was measured using four items, e.g., "If someone is half-drunk, I don't mind him riding a bike", "Everyone taking part in traffic has to be sober". Response options ranged from $1=$ totally disagree to $5=$ totally agree $(a=.78)$.

Personal norm: safety for self. Personal norm regarding one's own safety was measured using two items: "I believe I should behave myself in traffic and not only when there's cops around", "I think it's important not to endanger myself". Response options ranged from $1=$ disagree to $5=$ agree (Pearson's $r=.51, p<.001$ ).

Personal norm: safety for others. Personal norm regarding other people's safety was measured using six items, e.g., "Everyone knows that participating in traffic is risky. If someone gets hurt because of me, too bad", "I would feel terrible if someone would get hurt because of me". Response options ranged from $1=$ disagree to $5=$ agree $(a=.64)$.

Perceived risk taking. Risk taking was measured using three items: "How much risk do you take in traffic as a cyclist on your own?", "how much risk do you take in traffic as a cyclist in a group of friends?", "how much risk do you take in traffic as a pedestrian?". Response options ranged from $1=$ I don't take risks to $5=$ quite a lot of risk $(a=.71)$.

Personal experience with accidents. Two items measured participants' own experience with accidents: "Did you have an accident in the past two years so severe that you had to visit a doctor or hospital?"; response options were $1=$ no, 2 = nothing serious, 3 = had to see $a$ doctor, and 4 = went to hospital; "Did you have an accident in the past two years in which you only had material damage?"; ranging from $1=$ no to $4=$ more than twice. The scores on these items were combined to form one index of personal experience (Pearson's $r=.31, p<.001$ ).

Near accidents. One question measured near accidents: "How often did you almost have an accident", with response options ranging from 1 = practically never to 4 = practically every week.

\section{Results}

Risky cycling behavior and intentions

Means and standard deviations of the social-cognitive variables, intentions and 


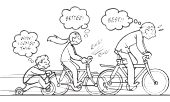

behavior are presented in Table 4. Correlation analysis was used to determine bivariate (inter)relationships of the social-cognitive variables with self-report measures of dangerous cycling behavior as well as intentions to perform dangerous behavior in the next month (see Table 4). Only those variables with correlations $>.05(=p<.05)$ with behavior or intention were selected in a multivariate regression to determine the amount of explained variance in behavior.

\section{Predicting risky cycling behaviors}

A regression analysis was run using the Enter method, where the variables correlating $(r$ 's $>.09 ; p<.001)$ with the behavior scale were entered in four blocks (Table 5). In the first block the so-called proximal variables (i.e., self-efficacy, attitudes, and norms) were entered. These proximal variables were able to explain $17 \%$ of the total variance in risk behavior. In the second block past experience with (near) accidents was added, which lead to an increase of $2 \%$ in explained variance. In the third block sex was added (an increase of $1 \%$ in explained variance), and in the final block perceived risk taking and intention. The full model explained $29 \%$ of the total variance in risky cycling behavior.

\section{Predicting risky cycling intentions}

A regression analysis was run using the Enter method, where all variables correlating with the intention scale were entered in four blocks (Table 5). The same configuration was used as before with the behavior scale. The proximal variables were able to explain $23 \%$ of the total variance in intention. Adding past experience with (near) accidents to the model led to an increase of $4 \%$ in explained variance. Sex did not increase the amount of explained variance any further. The addition of perceived risk taking and risky cycling behavior led to $37 \%$ of the total variance in intention to be explained by the full model.

To correct for the influence of the different schools, the data were also analysed using hierarchical linear modelling with school as random effect variable. These analyses yielded identical findings. The amount of variance in the outcome variables explained by school membership was less than $1 \%$.

\section{Discussion}

The object of this article was to identify relevant social-cognitive correlates of unsafe cycling behaviors. In this study ten determinants of behavior and intention 


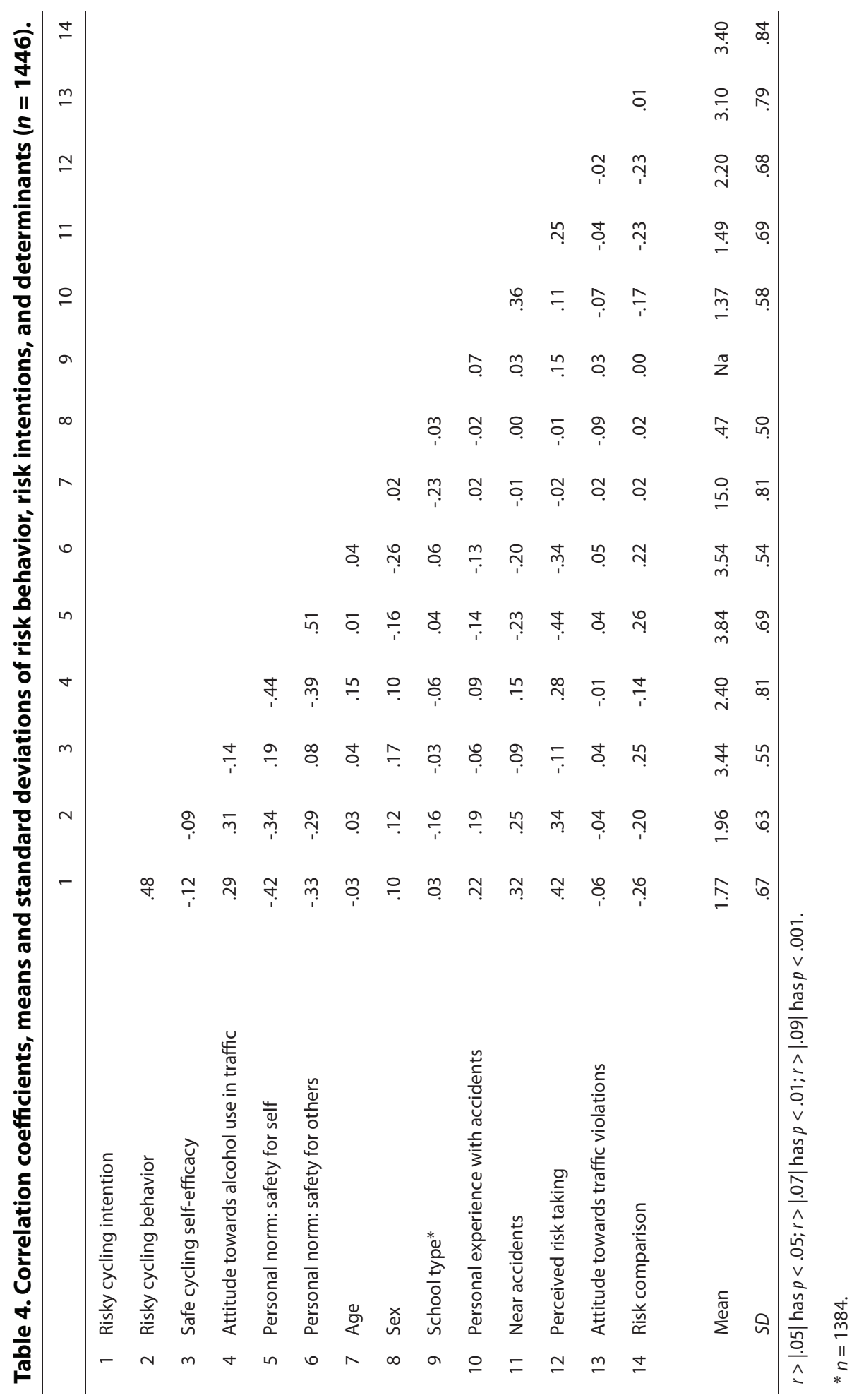




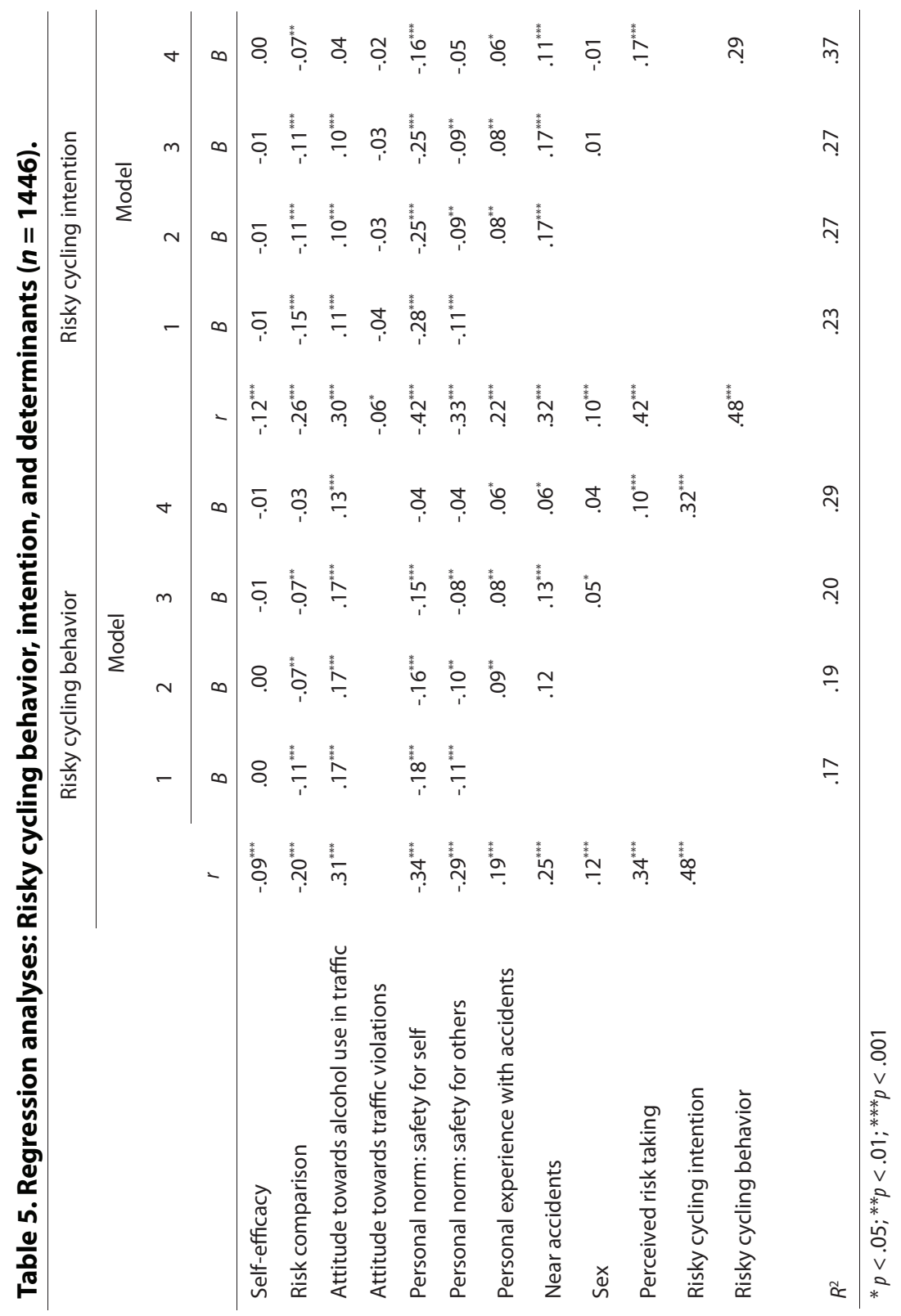


were identified (i.e., sex, self-efficacy, risk comparison, attitude toward alcohol in traffic, personal norm towards not endangering one's self, personal norm towards not endangering others, past accident involvement, near accident involvement, perceived risk taking, and intention to behave risky for behavior and vice versa). More specifically, the object of this study was to identify those social-cognitive correlates that are useful for interventions aiming to change behavior. Since the variables in the three latter blocks are either unchangeable (sex, prior experience), practically similar to the dependent variable (perceived risk taking), or measured simultaneously (intention), the focus regarding the results should be on the proximal variables (i.e., self-efficacy, risk comparison, attitude towards alcohol in traffic and the personal norms). These five variables were able to predict $17 \%$ of the variance in unsafe adolescent cycling behavior and $23 \%$ of the variance in risky cycling intentions.

The measures of attitudes, norms, and self-efficacy were correlated with intentions and behavior in an unsurprising way. Self-efficacy towards safe cycling skills was negatively correlated with risky cycling behavior and risky cycling intentions. Participants scoring high on personal norm to keeping one's self and others safe scored lower on risky cycling behavior and risky cycling intentions. Having a positive attitude towards being under the influence of alcohol related to higher scores on both risky cycling behavior and risky cycling intentions. However, the two variables measuring experience with accidents and near accidents were both positively associated with more risk taking. This positive association could mean two things. First, adolescents with risky cycling styles may encounter more dangerous situations and may therefore encounter more accidents and near accidents. Second, adolescents who report having an accident or near accidents in the past two years report dangerous cycling behavior during the past month. The latter explanation suggests that adolescents do not automatically learn from (near) accidents and thus do not change their risky behavior based on previous experiences, which is in line with Reyna and Farley (2006). From the regression analysis we could conclude that adolescents taking more risks in traffic (or intending to) see themselves more as risk takers, care less about their own safety and that of others, and are more tolerant of drunken driving.

The present study has some limitations. First and foremost, the variables used to predict behavior were not measured in the best possible way (Armitage \& Conner, 2000), namely on the same level as the behavior (cf. correspondence principle; Fishbein \& Ajzen, 1975). At the start of this study little was known about specific risky behaviors. Essential knowledge on the relation between 


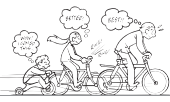

cycling behaviors and accident involvement is still lacking. In order to promote safer cycling we must know more about this relationship. However, adequate epidemiological studies into this relation are very complex (Iversen \& Rundmo, 2004) and are currently unavailable. Besides, because questionnaires have to be short in order to guarantee completion by adolescents, it was impossible to create items for variables like self-efficacy and personal norm corresponding to every single risky behavior.

Second, this study did not systematically explore all potentially relevant social-cognitive determinants from current behavior models, such as the Social Cognitive Theory (Bandura, 1989). For instance, social influence of peers might also be a determinant of adolescents' risky traffic behavior (Gardner \& Steinberg, 2005).

Future studies should also include other potentially relevant variables, i.e., automatic behavior or habits (Verplanken, 2006), subjective social norm, and descriptive norm. Furthermore, intention was not measured according to Theory of Planned Behavior. Rather, it was a combination of three questions reflecting Reason and colleagues' (1990) subdivision of errors. The reliability of intention was quite low, which raises questions about its validity. Nevertheless, the full model explained $37 \%$ of the variance in this measure of intention. Finally, behavior should ideally be measured at a later moment in time than the determinants to strengthen the causal interpretation of the associations between determinants and behavior.

\section{Conclusions}

In conclusion, the social-cognitive determinants measured in this study were moderately effective in predicting risky cycling behaviors measured with the self-report questionnaire. It is striking that adolescents' experience with accidents apparently does not promote safer traffic behavior. As mentioned in the introduction, this may be a reflection of the developmental stage adolescents are in. Adolescents are aware of their risk taking behavior and it seems evident that interventions to promote safer cycling should therefore not focus on risk perceptions. There is one possible exception as it might be useful to pay attention to susceptibility of accident involvement in relation to experience with (near) accidents. Near accidents occur more often than actual accidents. On the one hand adolescents might therefore learn that potential accidents usually have a positive ending (Houston, Johnson, Skinner, \& Clayton, 2006). On the other hand, 
they might learn that they lack of control over getting an accident, in which case some sort of helplessness is displayed. The corresponding cognition might be "it doesn't matter how I behave, I cannot control the occurrence of an accident". In that case self-efficacy towards safe cycling should be improved.

The focus of traffic education programs should thus be more on promoting traffic expertise (especially at an earlier age), acceptance of responsibility, selfefficacy (to increase the notion of control over their own behavior in relation to accident involvement), and probably resistance to social pressure (Steinberg \& Monahan, 2007), instead of on risk perception and fear. However, even if one would never display risky behavior in traffic, this can not diminish the risk of having an accident. In traffic, one is almost never alone and, except for 'onesided accidents' in which no other party is involved, an accident is almost always dependent on other traffic participants. Further studies on adolescents cycling should target other potentially relevant determinants, the prediction of future behavior, and the relationship between questionnaire measures of behavior and actual accident involvement. Furthermore, the cognitions of adolescents regarding near accidents should be studied. Near accidents may provide an opportunity for traffic education, because practically every traffic participant has a recollection of a 'close call'. It is important to know how people deal with these situations before interventions can be attuned to them. Taking all of the above into account, and following similar approaches in other domains of health promotion (Kroeze, Werkman, \& Brug, 2006; Noar, Benac, \& Harris, 2007; Noar, Black, \& Pierce, 2009), it should be possible to create safety interventions tailored to the needs of the target population. 




\section{Chapter 4}

\section{Evaluating Traffic Informers}

This chapter has been submitted for publication as: Feenstra, H., Ruiter, R.A.C., \& Kok, G. (submitted). Evaluating Traffic Informers: Testing the behavioural and social cognitive effects of a traffic safety education programs for adolescents. Accident Analysis \& Prevention. 
Teenagers are an identifiable risk group in traffic. Accident analyses have shown that adolescents (ages between 12 and 24) are particularly prone to be involved in traffic accidents. In the Netherlands, each year over 170 adolescents are killed in traffic and three thousand are hospitalized, accounting for $21 \%$ and $19 \%$ of all traffic fatalities and injuries respectively, whereas they account for $12 \%$ of the population (DVS, 2008). Adolescents in the pre-driver age category (i.e., under 18 years of age) are over-represented in the number of traffic fatalities and injuries (Wegman \& Aarts, 2006). In this age category, adolescents travel either by foot $(18 \%)$, by bicycle $(52 \%)$, by moped $(3 \%)$, or are driven by a parent or a friend (17\%), or by means of public transport (9\%; Wegman \& Aarts, 2006). Due to the lack of a protective vehicle (i.e., car, bus), the first three make the adolescent particularly vulnerable in traffic.

The bicycle is most popular in the Netherlands. An estimated 8 out of 10 inhabitants owns a bike (Lynam et al., 2005) and more than half of all trips made by 12 to 17 year olds are made by bike (Wegman \& Aarts, 2006). Most traffic safety programs target (young) car drivers, but even though the Netherlands are top-ranked among the safest countries in Europe there is also a need for traffic safety education programs targeting the more vulnerable adolescent road users. In this study we experimentally evaluated the Traffic Informer program that aims to promote safe traffic behavior in the pre-driver population, with a specific focus on bicycle use.

A large body of empirical evidence regarding risk behavior and adolescent decision making has accumulated over the years, especially in the context of driving (for an overview, see Eby \& Molnar, 1998). However, epidemiological data is scarce when it comes to the pre-driver population (Briem, Radeborg, Salo, \& Bengtsson, 2004; Durkin, Laraque, Lubman, \& Barlow, 1999; Elliott \& Baughan, 2004; Evans \& Norman, 2003; Hasselberg, Laflamme, \& Weitoft, 2001; Nasar, Hecht, \&Wener, 2008; Rivara, Thompson, \& Thompson, 1997). This is mainly due to the systematic underreporting of accidents and causes thereof when there are no cars involved (Reason, Manstead, Stradling, Baxter, \& Campbell, 1990). The lack of research attention for the pre-driving population also resulted in a lack of knowledge about the underlying social cognitive factors that motivate risky traffic behavior, which hinders the systematic evaluation of traffic education programs. Instead, knowledge about underlying social cognitive factors that mediate predriver risky traffic behavior is derived from the application of general explanatory models of health behavior (Armitage \& Conner, 2000; Brewer et al., 2007; Caspi et al., 1997; Cooper, Wood, Orcutt, \& Albino, 2003) and general traffic behavior theories (Rothengatter, 2005; Ulleberg, 2001; Ulleberg \& Rundmo, 2003). Factors 


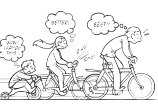

that have been identified as potential correlates of risky behavior in the pre-driver population include general risk perception (Chapman \& Groeger, 2004; Colbourn, 1978; Deery, 1999), specific risk perception in traffic (Arnett, Offer, \& Fine, 1997; Beullens \& Van den Bulck, 2008; Bina, Graziano, \& Bonino, 2006; Bingham \& Shope, 2004; Dahl, 2008; Harré, 2000; Harré, Field, \& Kirkwood, 1996; Keating \& HalpernFelsher, 2008; Kellermann \& Martinez, 2008; Machin \& Sankey, 2008; Nell, 2002; Rundmo \& Iversen, 2004; Shope, 2006), parental influence (Simons-Morton, Ouimet, \& Catalano, 2008; Simons Morton \& Hartos, 2003), and the effect of peers on risky traffic behavior (Dishion, McCord, \& Poulin, 1999; Engstrom, Gregersen, Granstrom, \& Nyberg, 2008; Gardner \& Steinberg, 2005; Grosbas et al., 2007; Steinberg \& Monahan, 2007).

Many traffic safety interventions have been implemented in the school setting to educate the pre-driver population about traffic safety. However, only a very small number of these education programs have been systematically evaluated. As a result, the effectiveness of school-based traffic safety education is largely unknown. The lack of systematic evaluation is further accompanied by a lack of systematic development of traffic safety education. The value of theoryand evidence-based development and evaluation of educational interventions has been described in detail by various researchers in the health psychology domain (Bartholomew, Parcel, Kok, \& Gottlieb, 2006; Fishbein \& Cappella, 2006; Green \& Kreuter, 2005; Michie \& Abraham, 2004; Schaalma, Abraham, Gillmore, $\&$ Kok, 2004). For example, Bartholomew and colleagues have developed the Intervention Mapping protocol, a planning framework for the development and evaluation of theory- and evidence-based health promotion programs (Bartholomew et al., 2006; Kok, Schaalma, Ruiter, Van Empelen, \& Brug, 2004). In brief, Intervention Mapping requires interventionists to identify intervention change objectives, or change targets, and specify commonly-understood behavior change techniques that have been used to bring about these planned changes. By basing such decisions on previous evidence and documenting the way in which intervention materials are designed interventionists can communicate clearly about intervention content thereby facilitating replication and subsequent intervention development (Abraham, Kok, Schaalma \& Luszczynska, 2010).

In the present study, the school-based traffic safety education program Traffic Informers is under evaluation. Traffic informers was developed to decrease the elevated risk of pre-drivers in traffic. The program consists of an eight minute long video of traffic accidents and a 30-minute long narrative by a road victim in the classroom. The concept of Traffic Informers is based on traffic education programs 
used in Denmark, (e.g., traffic educators showing videos of tragic accidents, and playing out dramatic scenes in order to create awareness in school children) and traffic safety videos from the UK. The traffic Informer program is used in almost every school in the province of Limburg, the Netherlands. With approximately 600 sessions per year, about 80.000 students participated in the traffic informer program since 2002.

The most prevalent aspect of the Traffic Informer campaign is the use of fear appeals in order to motivate participants to be safer in traffic. A fear appeal is defined as a persuasive communication attempting to arouse fear in order to promote precautionary motivation and self-protective action (Rogers, 1983). The use of fear appeals is widespread and popular among health education practices, for instance in anti-smoking and anti-drug abuse campaigns (Witte, 1992; Witte \& Allen, 2000). The central persuasive argument that fuels these health campaigns is clear: vividly show people the negative health consequences of life-endangering behaviors and they will be motivated to moderate their current risk behavior and adopt more safe alternative behaviors. However, there is a large body of evidence disputing the use of fear arousal to motivate people to change their behavior (De Hoog, Stroebe, \& de Wit, 2005, 2007; Lewis, Watson, \& Tay, 2007; Lewis, Watson, White, \& Tay, 2007; Ruiter, Abraham, \& Kok, 2001; Taubman Ben-Ari, Florian, \& Mikulincer, 2000; Van Wel \& Knobbout, 1998; Witte, 1992; Witte \& Allen, 2000). In fact, there are examples where interventions based on fear arousal have yielded defensive responses including avoidance of the health information (Kessels, Ruiter, \& Jansma, in press), denial of the health risk (Liberman \& Chaiken, 1992), and increased risk behavior (Taubman Ben-Ari et al., 2000). To counter these defensive processes and promote self-protective action, theoretical frameworks of fear appeals emphasize the use of coping information that provides specific behavioral instructions on how to effectively deal with the health threat (Rippetoe \& Rogers, 1987; Rogers, 1983; Witte, 1992).

Below we report on the systematic evaluation of the Traffic Informer program as it was administered in its normal setting (i.e., in classrooms of secondary schools). A quasi-experimental design was used, in which an experimental group (intervention) was compared with a control group (no intervention, waiting list method) combined with a pretest - posttest design to control for possible differences at baseline. Since it was not apparent exactly which theoretical methods underlie the Traffic Informer program, constructs from common theories to explain human behavior were used to evaluate its effectiveness, predominantly the Theory of Planned Behavior (TPB; Ajzen, 1991) and protection motivation theory (Rogers, 1983). The main behavioral outcome of interest 
was cycling behavior, which is the most common mode of transport among young adolescents. It was expected that the program is effective in raising risk perceptions through its use of fear arousal. However, since the program lacks decent advice on how to cope with risky traffic situations, effects on indices of less risky cycling behavior (attitude, intention, behavior) were not expected.

\section{Method}

\section{Participants}

Participants in this study were 9 th to 11 th grade students $(N=1593)$ from various high schools in the province of Limburg, who ride their bicycle to school on more than three days a week. Nine school boards agreed to participate in the study. These schools varied in size (amount of students; range 250 - 3700 students) as well as level of education, which varied from strictly lower general secondary education, strictly higher general secondary education, or a combination of the two. The traffic informer program is widely used in Limburg. It was therefore impossible to have schools in the control condition that did not have any experience with this program and also did not intend to use the program. Instead, two schools that planned the Traffic Informer program later in the school year were used as control schools. Furthermore, experiences from previous use of the program taught the development team that the program is widely talked about in schools after its implementation, also by students who were not targeted. Due to this possible contamination of study conditions it was impractical to set up experimental and control conditions within one school.

\section{Procedure}

Testing took place between August 2006 and February 2007. After boards of directors accepted the invitation to participate in the study, an appointment was made to deliver the pen and paper questionnaires. The questionnaires were usually delivered to the traffic safety teacher or contact, who was then instructed to hand out the questionnaires in class, one week prior to the Traffic Informer Program. The traffic safety teacher or class mentor was responsible for the administration and collection of the questionnaires. One month after the Traffic Informer Program, the follow-up was administered in a like fashion to the classes in the experimental condition. In the control condition, follow-up took place within a one month to six weeks period after the first questionnaire had been filled out. 
At time of the baseline measurement there were 392 participants in the control group and 1201 participants in the experimental group. At follow-up, there were 232 participants in the control group (59\%) and 896 participants in the experimental group (75\%).

\section{Traffic Informer Program}

Participants in the experimental condition received the traffic intervention program as planned. Participants in the control group did not receive the program at time of testing, but later in the year. No other program was presented to the control group at time of testing. The traffic informer program as it is used in Limburg is called a 'classroom lesson' and it starts with an eightminute compilation of short advertorials made in collaboration with insurance companies. This video shows short clips involving re-enacted but detailed car crashes. The videos are graphic and dramatic, and presumably made to show how accidents can happen; in a blink of an eye when no attention is paid to the road. Scenarios include young men trying to impress girls, not wearing seatbelts, and road rage. After the video is stopped, the traffic informer tells a personal story about the traffic accident he or she was involved in, which usually lasts around twenty to twenty-five minutes. Finally, there is room for questions and perhaps discussion. All traffic informers available at time of testing had prior experience with the program and followed a set scenario tailored to their own needs.

The traffic informers. At time of testing, there were 13 traffic informers working in the program. Since every traffic informer has his/her own region to work in, only those traffic informers were used that were currently working in the schools where the study took place. In class, each traffic informer tells his or her own story. There are, therefore, 13 possible stories the participants could be confronted with.

The discussion. After the traffic performer has finished talking about his life and its main events, the students in the class are then asked to participate in a discussion with the traffic informer by asking those questions they may have after hearing the talk.

Objectives. The traffic informer program was neither developed systematically nor is it based on a clearly formulated theoretical foundation. The subsequent lack of specifically described objectives makes it hard to select relevant outcome measures and difficult to evaluate the program systematically. Based on the methods (e.g., fear appeals) used in the program, the obvious main objective is to give an insight into what may happen if you get into a traffic accident (i.e., the consequences are severe, if not deadly). The program aims to create awareness in its students about this severity. The program developers may well have 
hypothesized that an increase in awareness would lead to adjusted behavior, in this case less risky cycling behavior.

\section{Measures}

Outcomes. Participants to this study were asked to fill out a questionnaire one week before and one month after the program. The questionnaire contained two parts. The self-reported behavior questionnaire was designed to fit the Dutch population of adolescents - containing questions about cycling behavior (the most common means of transportation for children of this age). The other part of the questionnaire contained items concerning intention, self-efficacy, attitudes, risk perception, and previous experience with accidents.

Risky cycling behavior. Self-reported risky cycling behaviors were assessed with a questionnaire containing 22 items ( $a=.89$; see also Feenstra, Ruiter, Schepers, Peters, \& Kok, in press). Items that were used were for instance: "riding a bicycle while under the influence of marijuana or other drugs", "Riding in threes", "having to brake hard because a car approached faster than anticipated". Participants were asked to state the number of times they performed these risky cycling behaviors over the past month. Scores on the items ranged from $1=$ never to $6=$ always.

Risky cycling intention. Intention to perform risky bicycle behavior was measured by a combination of three questions reflecting Reason's subdivision of errors (Reason et al., 1990): The first question "How often in the next month do you intend to break traffic rules?" pertains to violations (a deviation from what is deemed safe), the second "How often in the next month do you expect to get in a potentially harmful situation because of an error you make in traffic?" pertains to mistakes (conscious but wrong decisions), and the third "How often in the next month do you expect to break traffic rules unknowingly?" to slips and lapses (unconscious errors). Scores ranged from $1=$ never to $6=$ always $(a=.60)$.

Safe cycling self-efficacy. Self-efficacy concerning traffic skills was measured using an average score on five issues $(a=.65)$ : “Compared to other cyclists of your age and sex, how do you perform: controlling the bicycle, applying traffic rules, traffic situation insight, ability to withstand temptations to take risks, and ability to withstand peer pressure". Response options ranged from $1=$ much worse to $5=$ much better. Higher scores represent more confidence in one's skills.

Risk comparison. Participants were asked about their comparative risk to have a traffic accident with a single item: "Compared to other bicycle riders of my age and sex my risk of having a traffic accident is..." with response options ranging from $1=$ much smaller to $5=$ much higher (Harré, Foster, \& O’Neill, 2005). 
Attitude towards traffic violations. Attitude toward violating traffic rules was measured using the combined score on five items (e.g., "It should be up to me whether I obey the traffic rules or not", "With no traffic in sight, stopping in front of a red light makes no sense"; $a=.67$ ). Response options ranged from $1=$ totally disagree to $5=$ totally agree with higher scores representing a more positive attitude towards making traffic violations.

Attitude towards drunk driving. Attitude towards drunk driving was measured using four items (e.g., "If someone is half-drunk, I don't mind him riding a bike", "Everyone taking part in traffic has to be sober"; $a=.77$ ). Response options ranged from $1=$ totally disagree to $5=$ totally agree. Scores were recoded so that high scores represent more positive attitude towards drunk driving.

Personal norm: Safety for self. Attitude towards one's own risk was measured using two items: "I believe I should behave myself in traffic and not only when there's cops around", "I think it's important not to endanger myself" $r=.50$ ). Response options ranged from $1=$ disagree to $5=$ agree. Scores were recoded so that high scores represent more responsibility regarding ones' own safety.

Personal norm: safety for others. Personal norm towards endangering others was measured using the average score on five items (e.g., "Everyone knows that participating in traffic is risky. If someone gets hurt because of me, too bad", "I would feel terrible if someone would get hurt because of me"; $a=.68$ ). Response options ranged from $1=$ disagree to $5=$ agree. Scores were recoded so that higher scores indicate more perceived responsibility towards others.

Relative attitude. To have a direct measure of attitude towards traffic safety, but avoid ceiling effects because of general positive evaluations of the importance and need for traffic safety, participants ranked traffic safety among six other health behaviors (i.e., "exercise", "healthy eating", "moderate drinking”, "not smoking", "not doing drugs", "having safe sex") in order of importance and making sense $(r=.52)$. Scores on the combined scale ranged between 1 and 7 and lower scores represent more positive attitudes toward traffic safety compared with other health behaviors.

Perceived risk taking. The participant's personal estimate of risk taking was measured using three items $(a=.72)$ : "How much risk do you take in traffic as a moped rider/bicyclist on your own?", "How much risk do you take in traffic as a moped rider/bicyclist in a group of friends?", and "How much risk do you take in traffic as a pedestrian?" Response options ranged from $1=I$ don't take risks to $5=$ quite a lot of risk. Higher scores represent more risk taking.

Accident experience. Two items measured participants' own experience with traffic accidents: "Did you have an accident in the past two years so severe that 
you had to visit a doctor or hospital?" (Response options were $1=$ no, 2 = nothing serious, 3 = had to see a doctor, and 4 = hospital), "Did you have an accident in the past two years in which you only had material damage?" with scores from $1=$ no to $4=$ more than twice. The scores on these items were combined to form one index of personal experience $(r=.34)$. Higher scores represent more experience with accidents.

Near accidents. One question measured the number of near accidents in which participants were involved: "How often did you almost have an accident", with response options ranging from $1=$ practically never to $4=$ practically every week. Higher scores represent more experience with traffic accidents.

\section{Statistical analyses}

In order to establish whether analyses should be done using the 'change from baseline' or the ANCOVA method, both methods were tested on Lord's ANCOVA paradox (Lord, 1967; Van Breukelen, 2006). Indeed, we found a difference between the Change from baseline and ANCOVA model (i.e., Lord's ANCOVA paradox) and tested whether both models would yield similar results for the control condition only. It became apparent that using the ANCOVA model, a difference between the two schools in the control condition was found, after which it was decided to opt for the Change from baseline model, which is also the safer model in case the study design is not a randomized controlled trial (Van Breukelen, 2006). Therefore, repeated measures analyses were used to evaluate the effect of the traffic informer program on the outcome variables. More specifically, the linear mixed model regression analysis module in SPSS (version 15.0) was used to accommodate for participants with missing values on either of the two measurements. It was not possible to retain information about which participants had seen which traffic informer, thus the traffic informer program had to be taken as a whole.

\section{Results}

\section{Baseline data}

Average age of the girls was 14.98 years $(S D=.83)$ at baseline, with ages ranging from 13 to 18. Average age of boys was $15.01(S D=.85)$ with ages ranging from 13 to 18 . There were 207 girls and 183 boys in the control condition versus 624 girls and 576 boys in the experimental condition. 


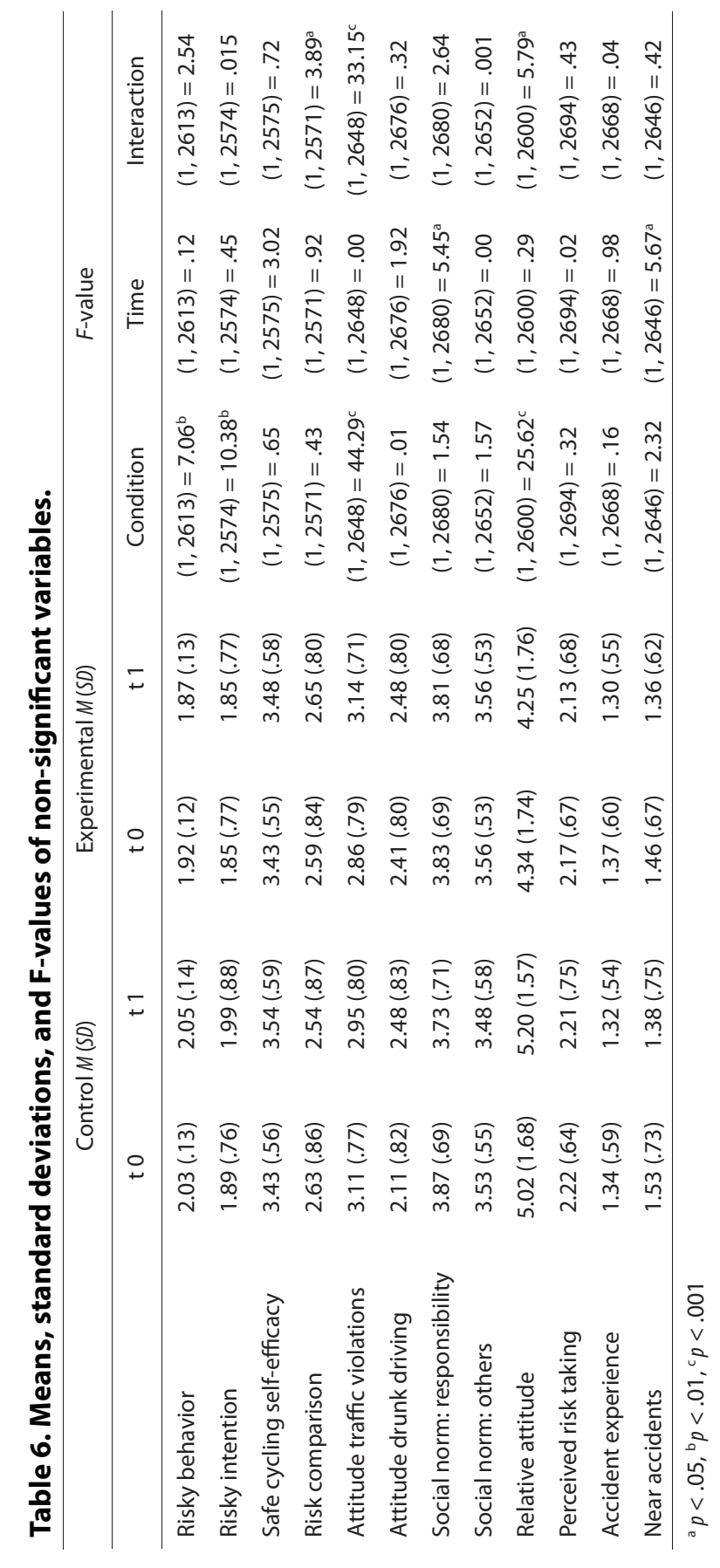


Outcomes

Outcomes of the Mixed Regression Analyses are displayed in Table 6. On three variables a significant effect of the intervention by time interaction was found, which describes the effect of the intervention. Subsequent simple effect analyses reveal the reasons for the interaction.

A significant interaction effect was found on attitude towards traffic violations. Simple effects analysis reveals at baseline a significant difference between the conditions, $F(1,1548)=25.91, p<.001$, Cohen's $d=.32$; participants in the control condition reported more positive attitudes towards making traffic violations than those in the experimental condition. After the intervention, this effect reversed, in that at follow-up there was a significant difference between the conditions, $F(1,1099)=10.49, p<.01$, Cohen's $d=.26$, with participants in the experimental condition reporting more positive attitudes towards traffic violations than those in the control condition. Note that this effect is contrary to the program objectives.

Another significant interaction effect was found on the variable risk comparison. Single effect analyses show at baseline no significant difference between conditions, $F(1,1528)=.50, n s$, Cohen's $d=.04$; participants in the experimental condition scored as high as participants in the control condition. At follow-up a significant difference between conditions was found, $F(1,1040)=$ $4.11, p<.05$, Cohen's $d=.16$. Participants in the experimental condition indicated their risk when compared to others of similar age and sex as higher than those in the control condition.

The last significant interaction effect was found on relative attitude. Single effect analyses showed a difference between conditions at baseline, $F(1,1534)$ $=22.66, p<.001$, participants in the control condition reported a less positive attitude towards traffic safety than those in the experimental condition. This effect became stronger at follow-up, $F(1,1066)=45.93, p<.001$, where participants in the control condition scored higher than before, and participants in the experimental condition scored lower than before. A low score means that traffic safety was ranked higher among other protective behaviors.

\section{Discussion}

The aim of this paper was to evaluate the traffic safety program Traffic Informers, which is currently practiced in the province of Limburg, the Netherlands. The program is widely adopted and both policy makers and users (i.e., boards of 
directors of schools and the students) are very enthusiastic about it. The program was not developed systematically; that is, the program was neither based on clearly formulated theoretical principles nor on available empirical evidence. Rather, the program developers adopted a confrontational approach, which is supposed to 'wake up' the participants, by showing videos of accidents and having a victim of an accident talk about the consequences in the classroom in order to raise awareness about the consequences of risky behavior in traffic. Without systematic development systematic evaluation is difficult, for it is unknown what change objectives were aimed for to reduce risky bicycle use (Bartholomew et al., 2006; Kok et al., 2004).

Not unexpected, therefore, the results of the present evaluation show little sign of effectiveness of the traffic informer program, both in the self-reported behavior of the participants and in intentions towards less risky traffic behavior. In fact, one of the three significant results we found appeared to be in the wrong direction. The attitudes toward violating traffic rules became slightly more positive after participating in the program. This result was significant, but had a small effect size. Two other significant results were in the right direction. First, after participating in the Traffic Informers program, students indicated that traffic safety was significantly higher on their priority list of health behaviors than before the program. Second, participants of the Traffic Informer program judged their own risk of getting an accident compared to their peers slightly higher than before the program. These results, however, had small to negligible effect sizes, which suggests that the significance of the results is more likely due to the amount of participants in the study, rather than to the effect itself.

There is an ongoing debate about the use of confronting messages (or fearappeals) in health messages (Biener \& Taylor, 2002; Hastings \& MacFadyen, 2002; Janssens \& De Pelsmacker, 2007; Slavin, Batrouney, \& Murphy, 2007). It appears that the fear-arousing messages in the Traffic Informer program are not effective at all. These results are in line with several other studies that used fear-appeals. Psychologically, fear is a powerful tool to attract attention to something. The use of fear in awareness raising messages is therefore somewhat logical. Feararousing messages are hence often used in traffic safety campaigns, anti-smoking advertisements, and HIV/AIDS campaigns (Witte \& Allen, 2000). Contrasting lay beliefs about the effectiveness of fear appeals, several studies suggest that fear arousal may easily result in defensive reactions such as risk denial, biased information processing, and allocating less attention to the health information (Kessels et al., in press; Ruiter et al., 2001). Thus, the effectiveness of the fear appeal to achieve the desired goal of the message (i.e., change from risk behavior 


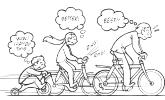

to safe behavior), depends on more than fear arousal alone (Ruiter, Abraham, \& Kok, 2001). Without advice on how to avert the consequences of the fear-arousing message, the possibility of negative side effects is all too real. For instance, Kessels and colleagues (in press) focused on the question whether fear appeals influence the extent to which we attend to health information. They found that the answer to this question is a definitive yes; we attend to threatening health information, but in a defensive way. Threatening information seems to motivate people to attend away from the health information. The use of confronting messages is often requested by those who are on the receiving end (e.g., the smokers, the risky drivers, the unsafe sexers), but they are really not experts on the effectiveness of such messages (Hastings \& MacFadyen, 2002; Ruiter \& Kok, 2005, 2006).

This study has some limitations. First and foremost, because the program itself was not developed systematically, a systematic evaluation closely geared towards the objectives of the program was practically impossible. However, the evaluation was performed as scientifically soundly as possible in a natural setting. Second, because of a lack of empirical data on specific risky behaviors directly increasing the risk of an accident in traffic, the variables used to predict behavior and intentions were not measured on the same level as the behavior, thus neglecting the correspondence principle (Fishbein \& Ajzen, 1975). Third, little theory was known before the start of this study about risky traffic behavior of cyclists. Many explanations have been put forward explaining why adolescents show more risky behaviors in general and specifically in traffic (Reyna \& Farley, 2006; Dahl, 2008; Keating \& Halpern-Felsher, 2008; Shope \& Bingham, 2008), but a theory providing tools for evaluating behavioral interventions to promote safe traffic behavior is lacking. In this study the theory of planned behavior was used, but for now it remains unclear whether and which risky cycling behaviors are planned or not. Finally, quasi-experiments in natural settings are always hard to evaluate, since many factors that can potentially influence the outcome cannot be controlled like they can in an experimental setting. The evaluation of the Traffic Informer program suffered the same problem, including the choice of analysis methods. However, the large amount of students participating in this study should have at least revealed sturdy effects, if there were any.

As a first step in the development of theory- and evidence-based interventions, a clear insight into what exactly constitutes the risk behaviors of adolescent cyclists (and moped riders) is essential. When specific behaviors contributing to an increased risk in traffic are identified, the determinants of these specific behaviors must be identified. Only then can interventions be designed to 
target those determinants in order to change the risky behavior into the desired safe behavior. As epidemiological data about specific risky behaviors of cyclists is unavailable, there lies an opportunity for future research.

In conclusion, the Traffic Informer program does not seem to have the desired effect (i.e., a change in behavior in a safe direction). Luckily, the evidence pointing in the direction of any negative side-effects of the program is minor. For the development of future interventions and programs targeting adolescents in traffic, more research is needed to find effective behavioral change techniques for promoting safe traffic behavior and the translation thereof in effective educational programs, other than the use of confronting and fear-invoking messages. Perhaps the Traffic Informers program does have positive effects on other, non traffic safety related issues, such as attitudes towards road victims, in which case the program should be continued, but not under the traffic safety denominator. The time and money spent on continuation of the traffic informer program could be better spent on improving it, or on developing new and better traffic safety programs. 




\title{
Chapter 5
}

\author{
Reaction time \\ differences between \\ adults and adolescents \\ in evaluating risky \\ traffic situations
}

This chapter has been accepted for publication as: Feenstra, H., Ruiter, R.A.C., \& Kok, G. (2011). Go Fast! Reaction time differences between adults and adolescents in evaluating risky traffic situations. Journal of Health Psychology. 
According to "fuzzy-trace theory" (Reyna, 2005) there are two paths of information processing in risky decision making. The first is highly deliberate and rational, in that it focuses on facts and details (e.g., weighing pros and cons when making a decision). The second path focuses on the gist or overall meaning of a situation and relies more on intuition than on deliberate reasoning (Reyna, 2004). According to Reyna, the former path is most often used by children and young adolescents, whereas the latter is used more with greater age and experience (Reyna \& Farley, 2006). This could explain why adolescents are, for instance, more at risk in traffic than adults.

In traffic, people are constantly required to make choices critical to their safety. Speed and correctness of a choice determine the outcome of a manoeuvre. Choice reaction times are therefore important in traffic research (Guerrier, Manivannan, \& Nair, 1999). Adolescents are indeed more than adults at risk in traffic. Whereas adolescents aged 15 to 24 years comprise only $12 \%$ of the population in the Netherlands, they account for a disproportionate $21 \%$ of the fatal injuries in traffic (DVS, 2008). This is not only the case in the Netherlands; similar results can be found in other western countries, for instance the United States (Sleet \& Ballesteros, 2009). Several reasons for these findings emerged from empirical research, ranging from pubertal reactions (e.g., sensation seeking, risk perceptions, etc.) to immature brain development (Reyna \& Farley, 2006).

Reyna and Farley (2006) refer to Baird and Fugelsang (2004) when stating that adolescents show longer reaction times in a choice reaction task when responding to questions such as 'is it a good idea to swim with sharks'. However, in Baird and Fugelsang (2004) there is no reference to such a study. Baird, Fugelsang, and Bennet (2005) is the only reference available to date with respect to the 'bad idea' study. Reyna and Farley (2006) conclude that, when reacting to risks, adolescents are slower than adults. The question remains whether this difference in reaction time is only found when a response to a risk is required, or whether adolescents are slower than adults in general.

Reaction time is the amount of time it takes for someone to detect a stimulus (e.g., a road hazard) and to respond to it. According to Green (2000) driver reaction time consists of three segments, namely mental processing time, movement time, and device response time. The device response time depends on the physical device (e.g., the vehicle) and is thus not the subject of this article. The human factor has a cognitive (mental processing time) and a physical element (movement time). The mental processing time can further be decomposed into sensation time (i.e., the time to detect an object), perception time (i.e., the time it takes to recognize the meaning of an observed object), and response selection 


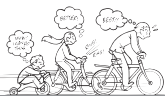

and programming time (i.e., the time it takes to decide which response to make and to program the movement; Green, 2000). There are influencing factors of reaction time on every level. Reaction times increase when signals are less intense (e.g., loudness, brightness, etc.), less probable or ambiguous (e.g., signal location, time, form), and when there are multiple response possibilities. Choice reaction times are generally slower than simple reaction times (i.e., only one signal or one response option), as are more complex movements (Green, 2000).

That adults are faster than adolescents has already been shown on various occasions. For instance, when Riddervold and colleagues (2007) examined the potential adverse effects of mobile phones, they found that adults are $4 \%$ faster than adolescents when measuring response speed to a visual target either in a simple task or in a complex task. When studying attentional bias to fearconditioned cues among children, adolescents, and young adults, Van Damme and Crombez (2009) found a decrease in reaction time with increasing age. Choudhury and Blakemore (2006) also report studies in which adults tend to be faster than adolescents in reaction time tasks. However, to our knowledge, these findings have never been reported in a study on traffic risk response. This study aims to provide evidence that there might be a relationship between accident rates of adolescents and adults and their reaction times.

In sum, increased traffic risks of adolescents have been explained by slower reaction times during risky traffic situations (Reyna \& Farley, 2006). The evidence for this has been limited to a conference paper. Here we aim to provide more evidence for the assumption that adolescents are more at risk than adults because adolescents respond slower to threats. Both risky and not risky situations are presented to adults and adolescents. It is hypothesized that adults will respond faster than adolescents to both types of situation.

\section{Method}

\section{Participants}

Twenty-six adolescent boys (Age range 14-18 years, Mean age $=15.8$ years, SD $=1.07$ ) and twenty-six adult men (Age range $40-60$ years, Mean age $=47.6, S D$ $=4.45$ ) who were present on a Saturday in May 2009 at a field hockey club in The Hague, the Netherlands, were asked to volunteer in the experiment. Even though participation in the experiment was voluntary, participants were entered in a raffle in which they could win an mp3-player. All participants were tested on the same day. Participants were restricted to males in order to reduce variance 
attributable to sex differences in traits such as sensation-seeking, which might influence risk preferences (Steinberg, Albert, Cauffman, Banich, Graham, et al., 2008), and sex differences in brain maturation (Giedd, Blumenthal, Jeffries, Castellanos, Liu, et al., 1999).

\section{Procedure}

Four laptop computers were installed in a separate room in the clubhouse. Up to four participants at a time were seated in front of a laptop computer. First, participants were given verbal instructions (e.g., be silent, look at your own screen, work as fast as possible) by the experimenter. These instructions were repeated on screen. The informed consent was also written on screen, and could be given by pressing the Enter key.

Next, a practice trial using correct and incorrect statements was presented. This was to ensure that participants knew which button to push upon answering the questions presented on the screen. One question at a time was asked (e.g., "Apples grow on trees" for correct items and "Three times four equals nine" for incorrect items). To avoid variation in reaction time due to people's preferred hand; participants were randomly assigned to two conditions: the left-yes condition (in which the q-key represented yes and the p-key no) or the right-yes condition (in which the p-key represented yes and the q-key no). The assigned keys were used throughout the task to minimize confusion.

After the practice trial, a baseline trial was presented in order to establish a general reading speed for each participant. Ten general questions were presented in random order. This measure would give insight into the reaction speed of the participants. There were five correct items (e.g.: "The daughter of the king is called a princess") and five incorrect items (e.g.: "Gloves are worn on the head").

Finally, four blocks (subsets) of trials were randomly presented. Within each block the individual items were also randomly presented. Items were presented using a sentence structure in the following manner: "Is it a good idea to..." followed by either a risky action ('bad idea') or a safe practice ('good idea') from one of four categories (i.e., the four blocks of trials): bicycle riding, scooter riding, car driving, and not vehicle related. For instance: "... drive under the influence of alcohol?" and "... ride without a working headlight at night?" ('bad idea'), or "... indicate when you're changing directions?" and "... keep both hands at the wheel?" ('good idea'). Again, participants had to respond by pressing one the keys associated with yes and no. Sentences were designed to measure between eleven and thirteen words (including "Is it a good idea to..."). It took about 5 minutes to read the instructions and finish the practice trial and another 15 minutes to 
complete the 85 test questions.

\section{Design}

The factors of interest were 'risk' (good idea vs. bad idea), subset (bicycle-, scooter-, car-, not vehicle-related), and age (adolescent vs. adult). The main outcome measure was the average response time to the risky and non-risky actions.

\section{Measures}

For the practice trial, baseline trial and main trial, reaction times were recorded for individual sentences using the E-Prime software (Psychology Software Tools Inc., Pittsburgh, PA). Time to respond started at the moment the sentence appeared on the screen and ended with the press of a button or after $10.000 \mathrm{~ms}$. Before analysis, each item was evaluated. When more than five (i.e., $10 \%$ of total) participants responded incorrect to the item, it was concluded that the item itself was unclear and it was excluded from the analyses. Cronbach's alpha was calculated after exclusion of the unclear items.

Reading speed. There were ten questions measuring reading speed. To three correct and two incorrect questions more than $10 \%$ of the participants responded incorrectly. These questions were excluded from the analysis. Average reaction times were calculated over the remaining items and used in further analysis as a covariate to control for reading speed (Cronbach's alpha $=.76$ ).

Cycling. There were fourteen 'bad idea' items regarding bicycle riding (e.g., "Is it a good idea to cycle under the influence of marijuana?") of which two were incorrectly answered by more than $10 \%$ of the participants. Of the ten 'good idea' items (e.g., "Is it a good idea to keep both hands on the wheel?") five items were incorrectly answered by more than $10 \%$ of the participants. 'Good idea' items were averaged ( 5 items, Cronbach's alpha $=.61$ ), and so were the 'bad idea' items (12 items, Cronbach's alpha $=.85$ ).

Scooter. There were sixteen 'bad idea' items concerning scooter riding (E.g., "Is it a good idea to push or pull a bicycle along?") of which two were incorrectly answered by more than $10 \%$ of the participants. Of the eleven 'good idea' items (e.g., "Is it a good idea to stick to the maximum speed?") also two items were incorrectly answered by more than $10 \%$ of the participants. 'Good idea' items were averaged (9 items, Cronbach's alpha $=.66$ ), and so were the 'bad idea' items (14 items, Cronbach's alpha $=.81$ ).

Car. There were six 'bad idea' items about car driving (e.g., "Is it a good idea to be drunk behind the wheel?") and six 'good idea' items (e.g., "Is it a good idea to 
keep distance from the car ahead?") of which one item was answered incorrectly by more than $10 \%$ of the participants. 'Good idea' items were averaged (5 items, Cronbach's alpha $=.74$ ), as were the 'bad idea' items ( 6 items, Cronbach's alpha $=$ .65).

Not vehicle related items. There were six 'bad idea' items related to general issues (e.g., "Is it a good idea to set your hair on fire?") and six 'good idea' items (e.g., "Is it a good idea to wash your hair on a regular basis?"), of which two items were incorrectly answered by more than $10 \%$ of the participants. An average reaction time was calculated over the 'bad idea' items ( 6 items, Cronbach's alpha $=.72$ ) as well as over the 'good idea' items (4 items, Cronbach's alpha $=.70$ ).

\section{Data analysis}

One adolescent participant was excluded from the analyses for having too high reaction times (i.e., a grand average score exceeding three standard deviations of the grand average of all participants). Reaction times of subsets of items were averaged and subjected to mixed ANCOVAs with the within-subjects factors subset (bicycle- vs. scooter- vs. car- vs. not vehicle-related) and risk (good idea vs. bad idea), the between-subject factor age (adolescent vs. adult), and as a covariate reading speed. Table 7 shows the mean reaction times and standard deviations of the adolescent and adult participants per subset.

\section{Table 7. Mean reaction times in milliseconds and standard deviations of adolescent and adult participants to 'good idea' and 'bad idea' stimuli ( $90 \%$ of participants answered correct).}

\begin{tabular}{lllccc}
\hline & & \multicolumn{4}{c}{ Reaction Times (ms) } \\
\cline { 3 - 6 } & & \multicolumn{2}{c}{ adolescent } & \multicolumn{2}{c}{ adult } \\
& & & \multicolumn{2}{c}{$N=25$} & \\
\cline { 3 - 6 } Subset & Items & 2166.69 & 512.71 & 2199.15 & 435.46 \\
\hline Baseline & & 2003.21 & 382.74 & 1831.85 & 318.68 \\
Bikes: & Good idea & 1735.62 & 394.93 & 1640.01 & 397.97 \\
& Bad idea & 1762.66 & 312.17 & 1643.69 & 272.54 \\
Scooters: & Good idea & 1736.20 & 327.80 & 1650.24 & 325.61 \\
& Bad idea & 1699.53 & 402.72 & 1562.46 & 356.83 \\
Cars: & Good idea & 1552.14 & 387.82 & 1408.31 & 262.16 \\
& Bad idea & 1907.56 & 501.25 & 1814.38 & 388.77 \\
General: & Good idea & 1806.63 & 413.89 & 1727,24 & 325,12 \\
& Bad idea & & & & \\
\hline
\end{tabular}




\section{Results}

On the measure of reading speed adolescents $(M=2166.69, S D=512.71)$ and adults $(M=2199.15, S D=435.46)$ did not differ significantly from each other, $t(1$, $49)=.24, n s$. The reading time measure was included as covariate in the further analyses.

There was a main effect of risk across the subsets of items, $F(1,48)=9.75, p$ $<.01, \eta_{\mathrm{p}}^{2}=.17$, showing that participants responded faster to 'bad idea' items ( $M$ $=1656.06, S D=305.47)$ than to 'good idea' items $(M=1760.72, S D=298.64)$. The main effect of group was also significant, $F(1,48)=4.34, p<.05, \eta_{p}^{2}=.08$. Adults responded faster $(M=1653.69, S D=266.30)$ than adolescents $(M=1765.29, S D=$ $317.07)$ to the subsets of items. Figure 1 summarizes the main effects of risk and group by showing the difference in reaction time between adolescents and adults for good and bad ideas.

Fig. 1. Reaction times in milliseconds

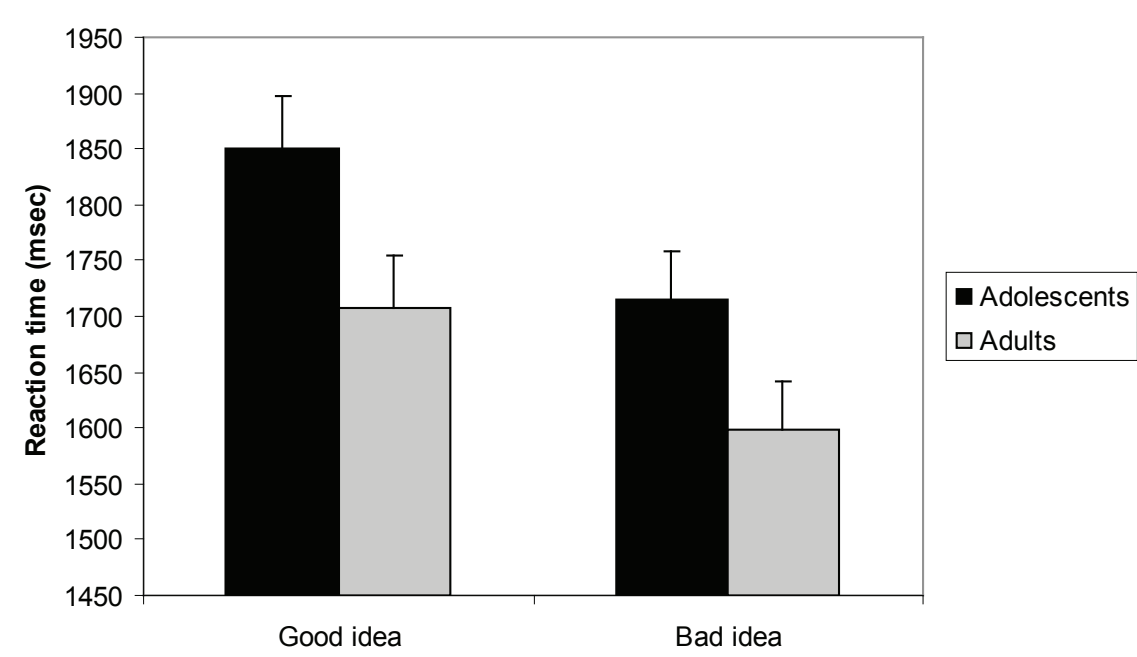

We found no main effect of subset, $F(3,144)=.51, n s, \eta_{\mathrm{p}}^{2}=.01$, neither did we find significant support for the interaction effects of subset $x$ age, $F(3,144)=.23, n s, \eta_{p}^{2}$ $=.01$, risk x age, $F(1,48)=.54, n s, \eta_{\mathrm{p}}^{2}=.01$, subset x risk, $F(3,144)=.60, n s, \eta_{\mathrm{p}}^{2}=.01$, and the three-way interaction of subset $x$ risk $x$ age, $F(3,144)=.19, n s, \eta_{p}^{2}=.00$. 


\section{Discussion}

The goal of this study was to investigate the possibility of adolescents responding slower to risky situations than adults. Such a result, combined with the fact that adolescents engage in risky activity more than adults, might provide insight into possible explanations for the increased risk of adolescents (for instance in traffic).

Overall, the results show that adolescents indeed appear to need more time than adults to decide whether something is either a good or a bad idea. In our study this result could not be attributed to a difference between adolescents and adults in reading speed. Both adolescents and adults respond faster if the item was a bad idea than if it was a good idea. The subject of the item did not matter. According to fuzzy-trace theory (Reyna, 2004; Reyna, 2005; Reyna \& Farley, 2006) adults should respond faster than adolescents, because they use gist-based intuition rather than a deliberation of the pros and cons of each behaviour. Indeed, these results have been found regularly (Baird, Fugelsang, \& Bennett, 2005; Choudhury, Blakemore, \& Charman, 2006; Riddervold et al., 2008; Van Damme \& Crombez, 2009) and are also in line with the findings of the present study.

However, one could argue that an interaction effect of age and type of item (good idea or bad idea) is expected in that the difference in reaction time between good ideas and bad ideas would be larger for adolescents than for adults. If adults indeed use gist-based intuition, a difference in response times between risks and non-risks is not expected, whereas in adolescents such a difference is expected. In the present study such an interaction effect was not found.

Contrary to our findings, Baird and colleagues (2005) found that participants responded faster to good ideas rather than to bad ideas (Baird et al., 2005). This is a rather unusual finding, since according to evolutionary psychology it would be beneficial to be able to respond faster to dangerous situations than to situations that pose no threat (Baumeister, 2005). Indeed, this evolutionary perspective could explain the difference between good ideas and bad ideas of adults in our study. Besides, Baird and colleagues (2005) found an interaction effect, in that the difference between good ideas and bad ideas was indeed larger for adolescents than for adults. Possible explanations for these differing results might be that in the present study only males were used, whereas Baird and colleagues studied both males and females. Adolescent males are thought to be more at risk than females. Adolescent females are also thought to mature earlier than adolescent males. It is not known whether adolescent males differ from adolescent females in 
responding to risks. Insight into this difference between males and females could further provide evidence for the assumption that slower reaction times increase risk in traffic.

Another possible explanation might be the age difference of the used samples. The adolescents in the Baird and colleagues' study had a mean age of 13 years and their adults had a mean age of 21 years. Even though the World Health Organisation defines adolescence roughly as being between 10 and 19 years of age, the upper limit is often stretched to as far as 25 years (Reyna \& Farley, 2006). Caufman, Steinberg, and Woolard (2002) found that adolescents between 10 and 13 years are more likely than other age groups to rate risky situations as dangerous, whereas they found no age differences in risk perception after 13 years of age (Caufman, Steinberg, \& Woolard, 2002; Steinberg, 2004).

This study has some limitations. Because only boys and men were used in this study nothing can be said about how these reaction times relate to women's reaction times. Future research on the differences between adolescents and adults should therefore include both male and female participants. Furthermore, reaction times may decrease again after a certain age (Guerrier et al., 1999). Finally, the sample size of this study was about three times larger than that of Baird and colleagues (2005), but the results of this study are not conclusive. It is therefore recommended that future studies include a much larger sample.

The results of this study suggest that reaction times decrease with age and that this is true for both risky and non-risky situations. It thus appears that older people decide faster whether a situation is risky or not. Suggestions derived from these results may stretch as far as advocating to increase legal age limits for risky activities such as riding a moped (from age 16 to 18 years) or driving a car (from age 18 to 21 ), and recommending the use of a graduated licensing system. 



\title{
Chapter 6
}

\author{
General \\ discussion
}


The goal of this thesis was to provide insight into the current state of affairs of traffic safety education aimed at adolescents. The effectiveness of one program in particular, Traffic Informers, was examined. In the course of the evaluation of this traffic safety education program, the effectiveness of a risky cycling behavior questionnaire was researched, the social-cognitive correlates of risky cycling behavior were studied, and the program itself was scrutinized. Furthermore, the assumption that adolescents are slower than adults when responding to threats was researched. Here, the findings of these studies will be discussed before the conclusions and implications of the separate studies are combined and some final remarks will be made.

\section{Overview}

Part of the plan of the regional body of traffic safety Limburg (ROVL) to eradicate all deaths from traffic accidents is to educate people about traffic safety. The goal of the ROVL is to decrease the amount of deadly traffic accidents to zero. Other provinces have since followed, albeit with somewhat more moderate objectives. For instance, the province of Zeeland recently announced the goal to eradicate all preventable deaths in traffic. 'Accidental' implies randomness of the cause of the injury. Traffic accidents are not random. Rather, researchers believe that traffic accidents are nonvolitional but nonetheless preventable. Therefore, researchers speak of unintentional injuries rather than accidental injuries. According to the ROVL mission statement, traffic behavior equals social behavior, requiring a lifelong learning process (www.rovl.nl/over-rovl/missie-en-visie).

In line with this vision, the ROVL promotes traffic safety education programs designed for different age categories, instead of programs aimed at the general public (mass media campaigns). Focus areas of the ROVL include (parents of) babies and small children, adolescents, young automobile drivers, and the elderly. This dissertation concerns traffic safety education programs aimed at adolescents.

Adolescents form an identifiable risk group with relatively high traffic accident statistics. Adolescents are involved in more accidents than one would expect from the size of their sample in the overall population. Whereas other subpopulations may sometimes be hard to target, adolescents are a popular target for health education program developers, due to school duty. Practically every teen will be in school during the day. Classroom activities are therefore often used in health education programs aimed at people in this age group. 
Measuring risky adolescent traffic behavior

Certain behaviors are thought to increase the odds of accidents more than others. These risk increasing behaviors are called risk behaviors. As Reason, Manstead, Stradling, Baxter, and Campbell (1990) proposed, the array of risky behaviors drivers perform can be divided into different types, each with a different frequency and intensity. Reason and colleagues differentiate (conscious) violations and errors, with a subdivision of errors in (conscious) mistakes and (unconscious) slips and lapses. Furthermore, each type of behavior may be linked to unintentional injuries in its own way. Besides, according to Reason and colleagues (1990), conscious decisions (mistakes and violations) may be understood as products of social and motivational factors, such as attitudes and norms. Hence, these deliberate acts could be changed through traffic safety interventions (Delhomme, De Dobbeleer, Forward, \& Simões, 2009), whereas unconscious slips and lapses may be more difficult to change. In chapter 2 a questionnaire that has been used in the Netherlands to measure risky cycling behavior of adolescents (ACBQ) was evaluated according to this subdivision of risky behaviors. The ACBQ was originally developed by the Dutch Institute for Traffic Safety Research (SWOV; Twisk, Vlakveld, \& Commandeur, 2007).

The ACBQ contains 22 questions concerning potentially risky cycling behaviors (e.g., "How often in the past month did you ...forget to signal when changing directions", "... ignore a red traffic light", and "...ride when having drunk alcohol?"). In line with Reason and colleagues (1990), the ACBQ was developed by the SWOV to estimate three types of behavior. In this chapter we aimed to identify the parametric properties of the $A C B Q$ and its relationships with injuries. Furthermore we investigated whether the distinction between violations and errors as proposed by Reason and colleagues (1990) would emerge in a large sample of adolescents. Almost 1750 secondary school students (ages between 13 and 18 years) filled out the questionnaire.

In order to obtain information on the parametric properties of the questionnaire, the data set was split into two equally large parts: a training data set and a test data set. The training data set was used in a parallel analysis to extract a factor solution. This factor solution was then used to fit on the test data set, which resulted in a model containing three factors. Afterwards, reliability analysis confirmed the internal consistency of the obtained factors. Factor analysis revealed that the three factors could be classified as "errors", "common violations", and "exceptional violations", with "common violations" being reported most often. Boys report common violations and errors more often than girls, but not exceptional violations. Exceptional violations are reported more often 
with increasing age, whereas common violations and errors remain fairly stable. Furthermore, the relations between the three factors and unintentional injury measures were analyzed using regression analyses. The results showed that the three factors were able to explain only small parts of the variance in accident frequency and accident severity ( $1 \%$ and $4 \%$ respectively), and a marginal part of the variance of near-miss frequency (15\%). From the results of this study it was concluded that the ACBQ is useful in measuring risky cycling behavior of adolescents, but that there are large parts in risky behavior left unexplained.

Because the three-factor model leaves so much variance in accident frequency and accident severity unexplained, there must be other factors than risk behavior of the adolescent cyclist causing unintentional injury and its severity. Other possible factors leading to unintentional injury and its severity include weather conditions, road conditions, other road participants, collision object, and many more. Risky behavior might increase the odds of accidents, but luckily the causal effect is not that strong. Even though there are many road accidents, road participation leaves room for erroneous behavior (both conscious and unconscious). Road users' perception of the relative safety of their actions probably adds to the frequency with which risky behaviors are performed (Ulleberg \& Rundmo, 2003; Martha \& Griffet, 2007).

What the ACBQ does not clarify is whether risk takers are more involved in road accidents than risk avoiders. Subjectively, the behaviors in the ACBQ can be described as risky, for they are deviations from what is considered safe practice, but future research will have to aim to identify which of the behaviors in the ACBQ actually and objectively increase risk in traffic. Furthermore, the identification of risk reducing behaviors will be beneficial for the development of interventions aimed at reducing adolescent bicycling risks.

\section{Correlates of risky adolescent traffic behavior}

In chapter 3 some possible determinants of risky adolescent cycling behavior were researched. Most safety education programs aimed at adolescents are based on accident statistics. Statistics show that adolescents are more at risk than adults in traffic. The main focus of safety education programs aimed at adolescents is risk perception. However, to the authors' knowledge no substantial research has shown that risk perceptions are the main (or only) cause of this increased risk or of the risky behavior causing the risk. In chapter 3 an attempt was made to identify the social-cognitive correlates of risky cycling behavior that may underlie the increased risky behavior of adolescents in traffic. Known constructs leading to behavior based on among others the Theory of Planned Behavior (e.g., attitudes, 
norms, risk perceptions, and intentions; Ajzen, 1991) were used as possible correlates of risky cycling behavior.

In this chapter I propose that program developers should identify "changeable" social-cognitive determinants of risky adolescent traffic behavior, prior to the development of traffic safety education programs. Some possible determinants of adolescent risky behavior, for instance biological changes (hormones leading to sensitivity for social approval and bravery) and a decrease in parental supervision, are considered part of adolescence and may prove extremely difficult to change. From a health education point of view, only changeable determinants (e.g., norms, self-efficacy and attitudes) are useful when trying to alter behaviors.

Both changeable and unchangeable possible determinants of risky adolescent traffic behavior as measured with the previously described ACBQ were used in a multivariate regression analysis to determine the amount of explained variance in behavior and intention. Even though some of the variance in risky cycling behavior (12\%) and risky cycling intentions (14\%) could be explained by unchangeable determinants (e.g., sex, age, previous accident experience), the largest amount of variance in risky behavior (17\%) and risky intentions (23\%) could indeed be explained by changeable determinants, in particular by attitudes, perceived social norms, and self-efficacy beliefs. Since a large portion of the variance can be explained by changeable determinants, identification of these determinants prior to traffic safety program development is advised. Even though it is interesting to know all the factors contributing to road accidents (involving bicyclists), it is a necessity to distinguish changeable factors from unchangeable factors (Bartholomew et al., 2006). A challenge in changing adolescents' risky behaviors (and intentions) lies ahead. While some behaviors may be explained using constructs from the Theory of Planned Behavior, others may not. Daily performed behaviors may be subject to habit forming, which makes behavior change all the more difficult (Reason et al., 1990).

\section{Evaluating a traffic safety education program aimed at adolescents}

The evaluation of a traffic safety education program aimed at adolescents is described in chapter 4. The Traffic Informers program has been very popular in secondary schools in the south of the Netherlands. Program developers as well as users of the program (teachers and students) are very positive about it. Maastricht University was asked to examine the actual effects of the program on correlates of adolescent traffic safety.

Traffic Informers was developed to raise awareness in adolescents about the 
risks of traffic involvement. According to the program developers, adolescents will adopt safer behavior when they become more aware of the risks in traffic. Methods used in the program are short videos of realistically re-enacted accidents (usually involving cars), confrontation with a traffic accident survivor, and a group discussion. The video that is shown is a compilation of short advertorials made in collaboration with insurance companies. The videos are graphic and dramatic, and presumably made to show how accidents can happen; in a blink of an eye when no attention is paid to the road. Scenarios include young men trying to impress girls, not wearing seatbelts, and road rage. The presence of the traffic accident survivor might add to the sought after effect of the videos. The Traffic Informer is visibly disabled due to the accident. After the video, he or she will discuss his or her life prior to the accident and explain how radical life changes due to an accident. The detailed explanation of the effects of a traffic accident is meant to inflict a desire in the participants of the study to avoid such an outcome, and therefore accidents, at all cost.

The effects of the program on risky cycling behavior, risky cycling intentions, attitudes towards using alcohol in traffic and breaking traffic rules, personal norms on responsibility, risk perceptions, as well as prior experience with accidents were investigated using the questionnaire discussed in chapters 2 and 3. In order to evaluate the program, a pretest - posttest experimental design was used. Participants of the study (students in secondary schools in the province of Limburg, the Netherlands, where the traffic informer program was already implemented and used for several years prior to this study), were divided into an experimental condition and a control condition. The same questionnaires were administered at the same interval for both conditions. Students in the experimental condition were subjected to the Traffic Informer program one week after the first measurement and one month before the second measurement, whereas students in the control condition were not subjected to the program in between the two measurements.

The Traffic Informers program does not appear to add to its participants' awareness of traffic risks. The results of this study have shown that adolescents were actually already aware of the risks in traffic. It is therefore probably safe to assume that there is no apparent need for an increase in awareness of traffic risks. The program did appear to have minor effects on the measure of compared risk. Before the program, participants indicated feeling less at risk of having a road accident than others of the same sex and age. After the program, the participants felt more at risk than before. Furthermore, participants were asked to rate traffic safety behaviors among other health behaviors in order of importance. Having 


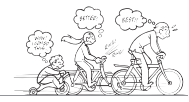

witnessed the program increased the perceived importance of traffic safety behaviors compared with a series of other health behaviors in a positive way. Participants rated traffic safety behaviors slightly more important after the program than before the program, however, the importance ratings never rose above the midpoint. The program also appeared to have a small unwanted effect: participants who witnessed the program were slightly more positive towards violating traffic rules than those who did not witness the program.

From the scientific literature it can be concluded that programs using fear appeals to change behavior are among the most often used and among the least effective behavior change programs (Albarracín, Gilette, Earl, Glasman, Durantini, \& Ho, 2005; Sheeran, 2006). Furthermore, it appears that personally relevant threatening information is often processed in a defensive, biased manner (Liberman \& Chaiken, 1992) or largely ignored (Kessels, Ruiter, \& Jansma, 2010).

\section{Exploring an alternative explanation of adolescent health risk}

In chapter 5, an often used hypothesis in traffic safety research was tested.

Referring to Baird and Fugelsang (2004), many researchers (e.g. Reyna \& Farley, 2006; Steinberg, 2007) claim that adults are faster than adolescents when responding to threats. To the author's knowledge, there is no scientific publication that supports this, except for a poster presentation by Baird, Fugelsang, and Bennet (2005). However, in various other domains it has been shown that adults have faster reaction times than adolescents. In order to test the hypothesis that adolescents are slower than adults when responding to threats, a choice-reactiontime task similar to the one used in the Baird, Fugelsang and Bennet (2005) study was used. In addition to this general threat task, specific traffic related tasks were also used.

Reaction times play an important part in accident analysis (Green, 2000). Longer reaction times in car driving lead to longer stopping distances, hence increasing crash probabilities. Green (2000) differentiates between mental processing time, movement time, and device response time. Mental processing time consists of sensation (detection of an object), perception (identification of the object), and response selection and programming (decide which response to make and program the movement). Movement time is the time it takes for the responder to perform the programmed movement, and device response time refers to the time it takes for a device to perform its response. Even though these processes may occur very fast, human differences in reaction time may have effects on traffic safety.

Reaction times may differ according to information processing style (Reyna, 
2004; 2005). According to Fuzzy Trace Theory, adolescents differ from adults in that the former process information in a highly deliberate and rational manner, whereas the latter process information more intuitively. The intuitive path of information processing requires less time than the rational path, indicating that adults may be faster when responding to (risky) situations than adolescents.

Twenty-six adult men and twenty-six adolescent boys responded as fast as possible to written situations on a computer. Situations ranged from everyday risky and non-risky situations (e.g., frying eggs in a pan, cooking chicken before eating it) to traffic specific risky and non-risky situations (i.e., concerning bicycles, cars, and mopeds). Participants had to decide whether they considered a given situation either 'a good idea' or 'not a good idea', by pressing one of two keys on a keyboard.

Results of the study showed that, in general, participants responded faster to 'bad idea' items than to 'good idea' items. From an evolution perspective, responding faster to risky situations than to riskless situations would be more beneficial than vice-versa. However, this result differs from the Baird and colleagues' study (2005) in which they report finding the opposite.

In our study adults responded faster to items, in general, than adolescents. These results are in fact in line with the 'fuzzy-trace theory' (Reyna, 2004; 2005), as well as with some of the results found by Baird and colleagues (2005). According to fuzzy-trace theory adults process information more intuitively than adolescents, who tend to process information rationally and deliberately, which takes longer. Baird and colleagues (2005) reported longer reaction times for adolescents regardless of stimuli type as well. However, some uncertainty still remains about the influence of reaction time differences between adults and adolescents in relation to risks.

In order to translate these results to advice, more research is indispensible. Details about what factors beside age influence reaction times should be researched as well as the influence of reaction times on accident involvement

\section{Reflections}

Credit must be given to the ROVL for their desire to have the traffic informer program evaluated. Evaluation of health education programs is indispensible for the development of increasingly successful programs. Without systematic evaluations, changing health behavior through health education seems like a lottery and the effectiveness of a program will be based more on luck than on 
wisdom and prior experience.

The participating schools (Table 8) deserve credit for their willingness to participate in this evaluation study, for their insight in adolescents' vulnerability and for their intention to teach their students to be safe traffic participants.

Table 8. Participating secondary schools

\begin{tabular}{llr}
\hline Name & City & Amount of students participating \\
\hline Trevianum & Sittard & 592 \\
St. Maartenscollege & Maastricht & 308 \\
Eijkhagen college & Landgraaf & 280 \\
Carboon/St. Janscollege & Hoensbroek & 235 \\
Lyceum Schöndeln & Roermond & 193 \\
Stella Maris & Maastricht & 116 \\
Hezeland college & Gennep & 102 \\
Broekhin & Roermond & 63 \\
Nikee & Roermond & 47 \\
\hline Total & & 1936
\end{tabular}

For the systematic evaluation of a health education program a systematic development of any program is preferred. Systematic development includes a clear outline of program objectives and methods of change to reach these objectives (Bartholomew et al., 2006, 2011). When a program is not developed systematically (e.g., lack of knowledge about underlying social cognitive factors of risky behavior), it is more difficult to tailor the evaluation instrument to the program design. In the case of the traffic informer program, this systematic development was lacking, thus making systematic evaluation difficult.

This dissertation aimed to provide a basis for future research on adolescent traffic safety. In the course of the past five years it has become apparent that there is definitely need for further research on this topic. For instance, more research is needed to identify risky behaviors and their determinants. Why are some people involved in accidents (some even in more than one during the course of their lives), whereas others are not? What sets them apart, how do they differ. What are the determinants of unintentional injuries? The influence of peers on accident involvement is another area that needs exploring (see e.g., Gardner \& Steinberg, 2005), as is the influence of personal and social norms regarding risky behavior. Furthermore, cognitions pertaining to risky behavior, accidents, and near-misses should be researched further. It is now still unclear in which direction relationships between behavior flow, and what determines the relationship 
between them.

\section{Conclusions and implications}

Traffic safety programs and health education programs aimed at changing behavior require a lot more than just a message. First of all, assuming people behave wrong, and telling them so, is unconstructive and may lead to defensive reactions. Fear may draw attention, but it is what is done with that attention that matters. Once a program creates behavior change intentions in participants, it must be clear what the desired response or behavior in a certain situation is. Besides, the participant must feel adequately capable of performing the desired behavior in that particular situation. Thus, changing behavior is more complex than simply telling people to change; even when people want to change their behavior, they struggle with actual change.

The road to (adolescent) traffic safety is paved with good intentions. Traffic accidents and subsequent unsafe feelings trigger strong emotional reactions in people. Obviously, people want to act upon these emotions and it is indeed positive that action is undertaken. However, intentions to change unsafe situations without proper knowledge and evidence-based methods are bound to fail. It seems like a waste that traffic safety education programs (Traffic Informers, for instance) are not as effective as intended. Traffic safety education programs should neither focus on accuracy of risk perceptions, nor on deliberately weighing pros and cons, but should promote risk-avoiding behaviors instead (Reyna \& Farley, 2006). More research is needed to gain more knowledge about riskdecreasing behaviors in traffic general (not just regarding bicycle behavior). It should be clear from this thesis that risk-increasing behaviors still need to be researched as well. Subsequently, a better understanding is required of the socialcognitive determinants of adolescent road use behaviors, since through those determinants behavior might be changed. Whereas many successful methods to change social-cognitive determinants of behavior are known, methods that take brain development, expertise development, and impulsivity control into account still need further developing. Finally, the focus of this thesis has been on adolescents and their responsibility for their own personal safety. Traffic safety, however, is not a matter of looking after your own. It's about looking out for others. 




\section{References}

Abraham, C., Kok, G., Schaalma, H., \& Luszczynska, A. (2010). Health Promotion. In P. R. Martin (Ed.), The International Association of Applied Psychology Handbook of Applied Psychology. Oxford: Wiley-Blackwell.

Ajzen, I. (1991). The theory of planned behavior. Organisational Behavior and Human Decision Processes, 50, 285-301.

Albarracín, D., Gillette, J. C., Earl, A. N., Glasman, L. R., Durantini, M. R., \& Ho, M. H. (2005). A test of major assumptions about behavior change: A comprehensive look at the effects of passive and active HIV-prevention interventions since the beginning of the epidemic. Psychological Bulletin, 131, 856-897.

Armitage, C. J., \& Conner, M. (2000). Social cognition models and health behavior: A structured review. Psychology and Health, 15, 173-189.

Arnett, J. J., Offer, D., \& Fine, M. A. (1997). Reckless driving in adolescence: 'State' and 'trait' factors. Accident Analysis \& Prevention, 29, 57-63.

Baird, A. A., \& Fugelsang, J. A. (2004). The emergence of consequential thought: Evidence from neuroscience. Philosophical Transactions of the Royal Society of London. Series B, Biological sciences, 359, 1797-1804.

Baird, A. A., Fugelsang, J. A., \& Bennett, C. M. (2005). "What were you thinking"? An fMRI study of adolescent decision making. Paper presented at the 12th Annual Cognitive Neuroscience Society (CNS), New York City.

Bandura, A. (1989). Human Agency in Social Cognitive Theory. The American Psychologist, 44, 1175-1184.

Bartholomew, L. K., Parcel, G. S., Kok, G., Gottlieb, N., \& Fernandez, M. E. (2011). Planning Health Promotion Programs: An Intervention Mapping Approach (3rd ed.). San Fransisco: Jossey-Bass.

Bartholomew, L. K., Parcel, G. S., Kok, G., \& Gottlieb, N. H. (2006). Planning Health Promotion Programs: An Intervention Mapping Approach (2nd ed.). San

Francisco: Jossey-Bass.

Basset Jr., D. R., Pucher, J., Buehler, R., Thompson, D. L., \& Crouter, S. E. (2008). Walking, cycling, and obesity rates in Europe, North America, and Australia. Journal of Physical Activity and Health, 5, 795-814.

Baumeister, R. F. (2005). The cultural animal: Human nature, meaning, and social life. New York, NY: Oxford University Press.

Beullens, K., \& Van den Bulck, J. (2008). News, music videos and action movie 
exposure and adolescents' intentions to take risks in traffic. Accident Analysis \& Prevention, 40, 349-356.

Biener, L., \& Taylor, T. M. (2002). The continuing importance of emotion in tobacco control media campaigns: a response to Hastings and MacFadyen. Tobacco Control, 11, 75-77.

Bina, M., Graziano, F., \& Bonino, S. (2006). Risky driving and lifestyles in adolescence. Accident Analysis \& Prevention, 38, 472-481.

Bingham, C. R., \& Shope, J. T. (2004). Adolescent problem behavior and problem driving in young adulthood. Journal of Adolescent Research, 19, 205-223.

Brewer, N. T., Chapman, G. B., Gibbons, F. X., Gerrard, M., McCaul, K. D., \& Weinstein, N. D. (2007). Meta-analysis of the relationship between risk perception and health behavior: The example of vaccination. Health Psychology, 26, 136-145.

Briem, V., Radeborg, K., Salo, I., \& Bengtsson, H. (2004). Developmental aspects of children's behavior and safety while cycling. Journal of Pediatric Psychology, 29, 369-377.

Caspi, A., Begg, D., Dickson, N., Harrington, H., Langley, J., Moffitt, T. E., et al. (1997). Personality differences predict health-risk behaviors in young adulthood: Evidence from a longitudinal study. Journal of Personality and Social Psychology, 73, 1052-1063.

Caufman, E. L., Steinberg, L., \& Woolard, J. (2002, April 13). Age differences in capacities underlying competence to stand trial. Paper presented at the Biennial Meeting of the Society for Research on Adolescence, New Orleans.

Chapman, P., \& Groeger, J. A. (2004). Risk and the recognition of driving situations. Applied Cognitive Psychology, 18, 1231-1249.

Chapman, P., Roberts, K., \& Underwood, G. (2000). A study of the accidents and behaviours of company car drivers. In G. B. Grayson (Ed.), Behavioural Research in Road Safety X. Crowthorne, UK: Transport Research Laboratory.

Chapman, P., \& Underwood, G. (2000). Forgetting near-accidents: the roles of severity, culpability and experience in the poor recall of dangerous driving situations. Applied Cognitive Psychology, 14, 31-44.

Choudhury, S., Blakemore, S.-J., \& Charman, T. (2006). Social cognitive development during adolescence. Social Cognitive and Affective Neuroscience, $1,165-174$.

Colbourn, C. J. (1978). Perceived risk as a determinant of driver behavior. Accident Analysis \& Prevention, 10, 131-141. 
Cooper, M. L., Wood, P. K., Orcutt, H. K., \& Albino, A. (2003). Personality and the predisposition to engage in risky or problem behaviors during adolescence. Journal of Personality and Social Psychology, 84, 390-410.

Dahl, R. E. (2008). Biological, developmental, and neurobehavioral factors relevant to adolescent driving risks. American Journal of Preventive Medicine, 35, S278-S284.

Davey, J., Wishart, D., Freeman, J., \& Watson, B. (2007). An application of the driver behaviour questionnaire in an Australian organisational fleet setting. Transportation Research Part F: Traffic Psychology and Behaviour, 10, 11-21.

De Hoog, N., Stroebe, W., \& De wit, J. B. F. (2005). The impact of fear appeals on processing and acceptance of action recommendations. Personality and Social Psychology Bulletin, 31, 24-33.

De Hoog, N., Stroebe, W., \& De wit, J. B. F. (2007). The impact of vulnerability to and severity of a health risk on processing and acceptance of fear-arousing communications: A meta-analysis. Review of General Psychology, 11, 258-285.

Deery, H. A. (1999). Hazard and Risk Perception among Young Novice Drivers. Journal of Safety Research, 30, 225-236.

Delhomme, P., De Dobbeleer, W., Forward, S. E., \& Simões, A. (2009). CAST Manual for Designing, Implementing, and Evaluating Road Safety Communication Campaigns. Brussels, Belgium: Belgian Road Safety Institute (IBSR-BIVV).

Dishion, T. J., McCord, J., \& Poulin, F. (1999). When interventions harm: Peer groups and problem behavior. American Psychologist, 54, 755-764.

Durkin, M. S., Laraque, D., Lubman, I., \& Barlow, B. (1999). Epidemiology and prevention of traffic injuries to urban children and adolescents. Pediatrics, 103, e74.

DVS. (2008). Road safety in the Netherlands, key figures. Ministry of Transport, Public Works and Water Management.

Elliott, M. A., \& Baughan, C. J. (2004). Developing a self-report method for investigating adolescent road user behaviour. Transportation Research Part F: Traffic Psychology and Behaviour, 7(6), 373-393.

Engstrom, I., Gregersen, N. P., Granstrom, K., \& Nyberg, A. (2008). Young drivers-Reduced crash risk with passengers in the vehicle. Accident Analysis \& Prevention, 40, 341-348.

European Road Safety Observatory (2006). Basic facts: Bicycles [Electronic Version]. Retrieved September 20, 2010 from http://ec.europa.eu/transport/ 
wcm/road_safety/erso/data/Content/bicycles.htm.

European Road Safety Observatory (2007). Basic facts: Young people [Electronic Version]. Retrieved September 20, 2010 from http://ec.europa.eu/transport/ wcm/road_safety/erso/data/Content/young_people.htm.

Evans, D., \& Norman, P. (2003). Predicting adolescent pedestrians' road-crossing intentions: An application and extension of the Theory of Planned Behaviour. Health Education Research, 18, 267-277.

Fallon, I., \& O'Neill, D. (2005). The world's first automobile fatality. Accident Analysis \& Prevention, 37, 601-603.

Feenstra, H., Ruiter, R. A. C., \& Kok, G. (2010). Social cognitive correlates of risky adolescent cycling behavior. BMC Public Health, 10, 408.

Feenstra, H., Ruiter, R. A. C., Schepers, J., Peters, G. J., \& Kok, G. (in press). Measuring risky adolescent cycling behaviour. International Journal of Injury Control and Safety Promotion.

Fishbein, M., \& Ajzen, I. (1975). Belief, Attitude, Intention, and Behavior. New York: Wiley.

Fishbein, M., \& Cappella, J. N. (2006). The role of theory in developing effective health communications. Journal of Communication, 56, S1-S17.

Fox, J. (2006). Structural equation modeling with the sem package in R. Structural Equation Modeling, 13, 465-486.

Gardner, M., \& Steinberg, L. (2005). Peer influence on risk taking, risk preference, and risky decision making in adolescence and adulthood: An experimental study. Developmental Psychology, 41, 625-635.

Giedd, J. N., Blumenthal, J., Jeffries, N. O., Castellanos, F. X., Liu, H., Zijdenbos, A., et al. (1999). Brain development during childhood and adolescence: A longitudinal MRI study. Nature Neuroscience, 2, 861-863.

Godin, G., \& Kok, G. (1996). The theory of planned behavior: A review of its applications to health- related behaviors. American Journal of Health Promotion, 11, 87-98.

Green, L. W., \& Kreuter, M. W. (2005). Health Program Planning: An Educational and Ecological Approach. (4th ed.). NY: McGraw-Hill Higher Education.

Green, M. (2000). "How long does it take to stop?" Methodological analysis of driver perception-brake times. Transportation Human Factors, 2, 195 - 216.

Grosbas, M. H., Jansen, M., Leonard, G., McIntosh, A., Osswald, K., Poulsen, C., et al. (2007). Neural mechanisms of resistance to peer influence in early 
adolescence. The Journal of Neuroscience, 27, 8040-8045.

Guerrier, J. H., Manivannan, P., \& Nair, S. N. (1999). The role of working memory, field dependence, visual search, and reaction time in the left turn performance of older female drivers. Applied Ergonomics, 30, 109-119.

Harré, N. (2000). Risk evaluation, driving, and adolescents: A typology. Developmental Review, 20, 206-226.

Harré, N., Field, J., \& Kirkwood, B. (1996). Gender differences and areas of common concern in the driving behaviors and attitudes of adolescents. Journal of Safety Research, 27, 163-173.

Hasselberg, M., Laflamme, L., \& Weitoft, G. R. (2001). Socioeconomic differences in road traffic injuries during childhood and youth: a closer look at different kinds of road user. Journal of epidemiology and community health, 55, 858-862.

Hastings, G., \& MacFadyen, L. (2002). The limitations of fear messages. Tobacco Control, 11, 73-75.

Houston, J. M., Johnson, J. A., Skinner, A. N., \& Clayton, M. V. (2006). Assessing aggressive driving: Comparing four self-report measures. North American Journal of Psychology, 8, 301-306.

Hu, L., \& Bentler, P. M. (1999). Cutoff criteria for fit indexes in covariance structure analysis: Conventional criteria versus new alternatives. Structural Equation Modeling, 6, 1-55.

Iversen, H., \& Rundmo, T. (2004). Attitudes towards traffic safety, driving behaviour and accident involvement among the Norwegian public. Ergonomics, 47, 555572.

Janssens, W., \& De Pelsmacker, P. (2007). Fear Appeal in Traffic Safety Advertising: The moderating role of medium context, trait anxiety, and differences between drivers and non-drivers. Psychologica Belgica, 47, 173-193.

Karlberg, L., Undén, A. L., Elofsson, S., \& Krakau, I. (1998). Is there a connection between car accidents, near accidents, and type A drivers? Behavioral Medicine, 24, 99-106.

Keating, D. P., \& Halpern-Felsher, B. L. (2008). Adolescent drivers: A developmental perspective on risk, proficiency, and safety. American Journal of Preventive Medicine, 35, S272-S277.

Kellermann, A. L., \& Martinez, R. (2008). Hot Wheels. American Journal of Preventive Medicine, 35, S310-S312.

Kessels, L. T. E., Ruiter, R., \& Jansma, B. (2010). Increased attention but more 
efficient disengagement: Neuroscientific evidence for defensive processing of threatening health information. Health Psychology, 29, 346-355.

Kok, G., Schaalma, H., Ruiter, R. A. C., Van Empelen, P., \& Brug, J. (2004). Intervention Mapping: Protocol for applying health psychology theory to prevention programmes. Journal of Health Psychology, 9, 85-98.

Kroeze, W., Werkman, A., \& Brug, J. (2006). A systematic review of randomized trials on the effectiveness of computer-tailored education on physical activity and dietary behaviors. Annals of Behavioural Medicine, 31, 205-223.

Lawton, R., Parker, D., Manstead, A. S. R., \& Stradling, S. G. (1997). The role of affect in predicting social behaviors: The case of road traffic violations. Journal of Applied Social Psychology, 27, 1258-1276.

Leventhal, H., \& Mora, P. A. (2008). Predicting outcomes or modeling process? Commentary on the health action process approach. Applied Psychology, 57, 51-65.

Lewis, I. M., Tay, R. S., \& Watson, B. (2003). The relationship between the thirdperson effect and the acceptance of fear-based road safety advertisement. In Proceedings Australian and New Zealand Marketing Academy (pp. 1970-1976). Adelaide, Australia.

Lewis, I. M., Watson, B., White, K. M., \& Tay, R. (2007). Promoting public health messages: Should we move beyond fear-evoking appeals in road safety? Qualitative Health Research, 17, 61-74.

Liberman, A., \& Chaiken, S. (1992). Defensive processing of personally relevant health messages. Personality and Social Psychology Bulletin, 18, 669-679.

Long, J. S. (1983). Confirmatory factor analysis. Newbury Park, CA: Sage.

Lord, F. M. (1967). A paradox in the interpretation of group comparisons. Psychological Bulletin 68, 304-305.

Lynam, D., Nilsson, G., Morsink, P., Sexton, B., Twisk, D., Goldenbeld, C. \& Wegman, F. (2005). An extended study of the development of road safety in Sweden, United Kingdom, and the Netherlands. Leidschendam, SWOV Institute for Road Safety Research / Crowthorne, Berkshire, Transport Research Laboratory TRL / Linköping, Swedish National Road and Transport Research Institute VTI.

Machin, M. A., \& Sankey, K. S. (2008). Relationships between young drivers' personality characteristics, risk perceptions, and driving behaviour. Accident Analysis \& Prevention, 40, 541-547.

Males, M. (2009). Does the adolescent brain make risk taking inevitable? A 
skeptical appraisal. Journal of Adolescent Research, 24, 3-20.

Martha, C., \& Griffet, J. (2007). Risk taking and risk perception in road safety: Comparative study of young sportsmen and nonsportsmen in southeastern France. Perceptual and Motor Skills, 104, 1243-1250.

Mesken, J., Lajunen, T., \& Summala, H. (2002). Interpersonal violations, speeding violations and their relation to accident involvement in Finland. Ergonomics, 45, 469-483.

Michie, S., \& Abraham, C. (2004). Interventions to change health behaviours: Evidence-based or evidence-inspired? Psychology and Health, 19, 29-49.

Mook, D. G. (2000). Psychological Research: The ideas behind the methods. New York, NY: W.W. Norton \& Company.

National Vital Statistics Report (2002). Vol. 50, No. 15 [Electronic Version]. Retrieved September 20, 2010 from http://www.cdc.gov/nchs/data/nvsr/nvsr50/ nvsr50_15.pdf.

Nasar, J., Hecht, P., \& Wener, R. (2008). Mobile telephones, distracted attention, and pedestrian safety. Accident Analysis \& Prevention, 40, 69-75.

Neisser, U., \& Harsch, N. (1992). Phantom flashbulbs: False recollections of hearing the news about the Challenger. In E. Winograd \& U. Neisser (Eds.), Affect and accuracy in recall: Studies of "flashbulb" memories (pp. 9-31). Cambridge, UK: Cambridge University Press.

Nell, V. (2002). Why young men drive dangerously: Implications for injury prevention. Current Directions in Psychological Science, 11, 75-79.

Noar, S. M., Benac, C., \& Harris, M. (2007). Does tailoring matter? Meta-analytic review of tailored print health behavior change interventions. Psychological Bulletin, 133, 673-693.

Noar, S. M., Black, H. G., \& Pierce, L. B. (2009). Efficacy of computer technologybased HIV prevention interventions: A meta-analysis. AIDS, 23, 107-115.

O'Connor, J., \& Saunders, B. (1992). Drug education: an appraisal of a popular preventive. International Journal of Addiction, 27, 165-185.

Ouimet, M. C., Morton, B. S., Noelcke, E. A., Williams, A. f., Leaf, W. A., Preusser, D. F., et al. (2008). Perceived risk and other predictors and correlates of teenagers' safety belt use during the first year of licensure. Traffic Injury Prevention, 9, 1-10.

Özkan, T., \& Lajunen, T. (2005). A new addition to DBQ: Positive Driver Behaviours Scale. Transportation Research Part F: Traffic Psychology and Behaviour, 8, 355- 
368.

Özkan, T., Lajunen, T., \& Summala, H. (2006). Driver Behaviour Questionnaire: A follow-up study. Accident Analysis \& Prevention, 38(2), 386-395.

Parker, D., Reason, J. T., Manstead, A. S., \& Stradling, S. G. (1995). Driving errors, driving violations and accident involvement. Ergonomics, 38, 1036-1048.

Parker, D., West, R., Stradling, S., \& Manstead, A. S. R. (1995). Behavioural characteristics and involvement in different types of traffic accident. Accident Analysis \& Prevention, 27, 571-581.

Pucher, J., \& Buehler, R. (2008). Making cycling irresistible: Lessons from The Netherlands, Denmark and Germany. Transport Reviews, 28, 495-528.

R Development Core Team (2008). R: A language and environment for statistical computing. (Version 2.8.1). Vienna, Austria: R Foundation for Statistical Computing.

Reason, J. (1990). Human Error. Cambridge: Cambridge University Press.

Reason, J. T., Manstead, A. S., Stradling, S. G., Baxter, J., \& Campbell, K. (1990). Errors and violations on the roads: a real distinction? Ergonomics, 33, 1315-1347.

Reason, J. T., Manstead, A. S. R., Stradling, S. G., Parker, D., \& Baxter, J. S. (1991). The social and cognitive determinants of aberrant driving behaviour. TRRL Research Report. Crowthorne, Berkshire, U.K.: Transport Research Laboratory.

Reyna, V. F. (2004). How people make decisions that involve risk. A dual-processes approach. Current Directions in Psychological Science, 13, 60-66.

Reyna, V. F. (2005). Fuzzy-Trace Theory (FTT), judgment, and decision-making: A dual-process approach. In C. Izawa \& N. Ohta (Eds.), Human Learning and Memory: Advances in Theory and Application: The 4th Tsukuba International Conference on Memory. New Jersey: Lawrence Erlbaum Associates.

Reyna, V. F., \& Farley, F. (2006). Risk and rationality in adolescent decision making; implications for theory, practice, and public policy. Psychological Science in the Public Interest, 7, 1-44.

Riddervold, I. S., Pedersen, G. F., Andersen, N. T., Pedersen, A. D., Andersen, J. B., Zachariae, R., et al. (2008). Cognitive function and symptoms in adults and adolescents in relation to rf radiation from UMTS base stations. Bioelectromagnetics, 29, 257-267.

Rippetoe, P. A., \& Rogers, R. W. (1987). Effects of components of protectionmotivation theory on adaptive and maladaptive coping with a health threat. Journal of Personality and Social Psychology, 52, 596-604. 
Rivara, F. P., Thompson, D. C., \& Thompson, R. S. (1997). Epidemiology of bicycle injuries and risk factors for serious injury. Injury Prevention, 3, 110-114.

Rogers, R. W. (1983). Cognitive and physiological processes in fear appeals and attitude change: A revised theory of protection motivation. In J. T. Cacioppo \& R. E. Petty (Eds.), Social Psychophysiology: a Source Book (pp. 153-176). New York: Guilford Press.

Rothengatter, T. (2005). Traffic Psychology and Road Safety: Seperate Realities. In G. Underwood (Ed.), Traffic and Transport Psychology. Theory and Application. Amsterdam, The Netherlands: Elsevier.

Ruiter, R. A. C., Abraham, C., \& Kok, G. (2001). Scary warnings and rational precautions: A review of the psychology of fear appeals. Psychology and Health, 16, 613-630.

Rundmo, T., \& Iversen, H. (2004). Risk perception and driving behaviour among adolescents in two Norwegian counties before and after a traffic safety campaign. Safety Science, 42, 1-21.

Schaalma, H., Abraham, C., Gillmore, M., \& Kok, G. (2004). Sex education as health promotion: What does it take? Archives of Sexual Behavior, 33, 259-269.

Sheeran, P. (2006). Does changing cognitions cause health behaviour change? Paper presented at the $20^{\text {th }}$ Annual Conference of the European Health Psychology Society (September). Warsaw, Poland.

Shope, J. T. (2006). Influences on youthful driving behavior and their potential for guiding interventions to reduce crashes. Injury prevention, 12(suppl_1), i9-14.

Shope, J. T., \& Bingham, C. R. (2008). Teen driving: Motor-vehicle crashes and factors that contribute. American Journal of Preventive Medicine, 35, S261-S271.

Simons-Morton, B. G., Ouimet, M. C., \& Catalano, R. F. (2008). Parenting and the young driver problem. American Journal of Preventive Medicine, 35, S294-S303.

Simons Morton, B. G., \& Hartos, J. L. (2003). How well do parents manage young driver crash risks? Journal of safety research, 34, 91-97.

Slavin, S., Batrouney, C., \& Murphy, D. (2007). Fear appeals and treatment sideeffects: An effective combination for HIV prevention? AIDS Care: Psychological and Socio-medical Aspects of AIDS/HIV, 19, 130 - 137.

Sleet, D. A., \& Ballesteros, M. F. (2009). Unintentional injuries among adolescents. In R. J. DiClemente, J. S. Santelli \& R. A. Crosby (Eds.), Adolescent Health: Understanding and preventing risk behaviors (pp. 249-274). San Fransisco, CA: John Wiley \& Sons. 
Steinberg, L. (2004). Risk taking in adolescence: What changes, and why? In R. E. Dahl \& L. P. Spear (Eds.), Adolescent brain development: vulnerabilities and opportunities (Vol. 1021, pp. 51-58). New York, N.Y.: The New York Academy of Sciences.

Steinberg, L. (2007). Risk Taking in Adolescence. Current Directions in Psychological Science, 16, 55-59.

Steinberg, L., Albert, D., Cauffman, E., Banich, M., Graham, S., \& Woolard, J. (2008). Age differences in sensation seeking and impulsivity as indexed by behavior and self-report: Evidence for a dual systems model. Developmental Psychology, 44, 1764-1778.

Steinberg, L., \& Monahan, K. C. (2007). Age differences in resistance to peer influence. Developmental Psychology, 43, 1531-1543.

SWOV. (2006). Factsheet Fietsers [Bicyclists]. Leidschendam, NL: SWOV Institute for Road Safety Research.

SWOV. (2010). Causes of death. Retrieved September 20, 2010, from http://www. swov.nl/nl/research/kennisbank/inhoud/90_gegevensbronnen/inhoud/ doodsoorzaken.htm

Taubman Ben-Ari, O., Florian, V., \& Mikulincer, M. (2000). Does a threat appeal moderate reckless driving? A terror management theory perspective. Accident Analysis and Prevention, 32, 1-10.

Twisk, D. A. M., Vlakveld, W. P., \& Commandeur, J. J. F. (2007). Wanneer is educatie effectief? [When is education effective?]. Leidschendam: SWOV.

Ulleberg, P. (2001). Personality subtypes of young drivers. Relationship to risktaking preferences, accident involvement, and response to a traffic safety campaign. Transportation Research Part F: Traffic Psychology and Behaviour, 4, 279-297.

Ulleberg, P., \& Rundmo, T. (2003). Personality, attitudes and risk perception as predictors of risky driving behaviour among young drivers. Safety Science, 41 , 427-443.

Van Breukelen, G. J. P. (2006). ANCOVA versus change from baseline had more power in randomized studies and more bias in nonrandomized studies. Journal of Clinical Epidemiology, 59, 920-925.

Van Damme, S., \& Crombez, G. (2009). Measuring attentional bias to threat in children and adolescents: A matter of speed? Journal of Behavior Therapy and Experimental Psychiatry, 40, 344-351. 
Van Wel, F., \& Knobbout, J. (1998). Adolescents and Fear Appeals. International Journal of Adolescence and Youth, 7, 121-135.

Verplanken, B. (2006). Beyond frequency: Habit as mental construct. British Journal of Social Psychology, 45, 639-656.

Verschuur, W. L. G., \& Hurts, K. (2008). Modeling safe and unsafe driving behaviour. Accident Analysis \& Prevention, 40, 644-656.

Wegman, F., \& Aarts, L. (2006). Cyclists and pedestrians. In F. Wegman \& L. Aarts (Eds.), Advancing sustainable safety (pp. 155-162). Leidschendam: SWOV Institute for Road Safety Research.

Witte, K. (1992). Putting the fear back into fear appeals: The extended parallel process model. Communication Monographs, 59, 329-349.

Witte, K., \& Allen, M. (2000). A meta-analysis of fear appeals: Implications for effective public health campaigns. Health Education Behavior, 27, 591-615. 



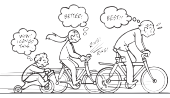

\section{Summary}

The Netherlands rank among the safest countries in Europe when traffic accidents are concerned. Traffic accidents are, however, the number one cause of death for adolescents (ages 12 - 24 years) in the Netherlands (as well as in Europe and in the United States of America). Adolescence is defined as the period between childhood and adulthood in which the child becomes physically mature, but not yet emotionally. In the Netherlands, adolescents mainly travel by bicycle, especially during the secondary school period (ages $12-17$ years). Even though cycling is generally considered healthy, it does entail relatively high safety risks. Responsible for the prevention of road accidents in the province of Limburg in the Netherlands is the Regional Consultation of Traffic Safety Limburg (ROVL).

The ROVL aims to reduce traffic accidents and fatalities to zero using traffic safety programs targeting the public at all ages (i.e., permanent traffic education). One of the traffic safety education programs targeting adolescents is Traffic Informers, a school-based program that aims to confront students with the possible effects of their behavior in traffic. In this program, students watch shocking videos of accidents after which they get to talk to an accident victim. The program is considered successful in that it is used by most secondary schools in Limburg. In line with their mission statement, the ROVL asked Maastricht University to evaluate the effects of the Traffic Informer program on the traffic behavior of adolescents. This dissertation is the result of this evaluation.

Chapter 1 starts with a description of the state of adolescent traffic safety in the Netherlands and a short review of available explanations regarding the increased risk of adolescents. The importance of systematic development of (safe traffic) education programs, and limitations of the use of fear-appeals (i.e., a message designed to elicit fear in an attempt to persuade an individual to pursue some predefined course of action) in education programs are discussed alongside a description of the Traffic Informer program.

The evaluation of the Traffic Informer program started with a literature search for risky cycling behavior. However, due to underreporting of accidents with bicycles there is hardly any epidemiological data on risky behaviors. Therefore, an available questionnaire developed by the Dutch Institute for Traffic Safety (SWOV; Twisk, Vlakveld, \& Commandeur, 2007) was used to determine what risky behaviors were performed by cycling adolescents and how they were linked to traffic accidents (Chapter 2). The questions in this questionnaire were developed following a subdivision of unsafe behaviors into conscious violations, conscious mistakes, and unconscious slips and lapses (Reason, 1990). This distinction 
has been successfully used in automotive research using the Driver Behavior Questionnaire (Reason et al., 1990), but it has never before been tested on bicyclists.

The aim of the study described in chapter 2 was to identify the parametric properties of the questionnaire, to consider its relationships with injuries, and to investigate whether the postulated distinction between violations and errors emerged in a large sample of adolescent cyclists. The results confirmed three factors, although they were slightly different than the three proposed by Reason (1990), namely errors (i.e., conscious mistakes and unconscious slips), common violations (i.e., everyday disregard of traffic regulations, like ignoring traffic lights), and exceptional violations (e.g., use of drugs). Common violations were reported more often than errors and exceptional violations. Boys reported more errors and common violations than girls, whereas older participants reported exceptional violations more often than younger participants. From the results of this study it was concluded that it can be useful to classify types of risky cycling behavior for explorative purposes. However, the effect sizes of the correlations between the three factors and accident involvement, accident severity, and near accident involvement were too small to make inferences about their predictive values.

In chapter 3 possible determinants of risky cycling behavior were examined using variables from known behavior models, like the Theory of Planned Behavior (Ajzen, 1991). Through determinants of behavior (e.g. attitudes towards risk taking, social norms about traffic safety, and self-efficacy beliefs), behavior can be changed. Before the start of this study little was known about the determinants of risky cycling. The results of the study showed that the measured social-cognitive determinants were moderately effective in predicting risky cycling behavior. The results also revealed that prior accident experience does not promote safer traffic behavior. Combined with the findings that adolescents accurately rated their risk behavior, it was concluded that safer cycling interventions should not focus on risk perceptions. In this chapter, I proposed to research correlates of risky cycling behaviors prior to the development of safety education programs, to select those correlates that positively influence safe traffic behavior, and to select those correlates that can be changed. Safer cycling education programs should focus on these changeable correlates.

Working with what we knew about potential determinants of risky cycling behavior; we measured the effects of the Traffic Informer program on these determinants in the evaluation (Chapter 4). Participants filled out questionnaires regarding risky cycling behavior, risky cycling intentions, and potential correlates of behavior and intention, before and after participating in the Traffic Informer 


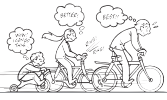

program. Differences between pre-test and post-test were compared with pre-test - post-test measures from a control group (i.e., a group that did not participate in the program). The results were disappointing, in that the few significant results that were found were accompanied by negligible effect sizes and therefore of little interest. The results of the evaluation of Traffic Informers are explained through evidence from studies on fear-appeals. A fear-appeal is a message that is aimed to induce feelings of fear in order to persuade the receiver of the message to change their current behavior. Even though fear is effective in drawing attention, its use in behavior change interventions is subject to many limitations. Whereas the use of fear-appeals is widespread, interventions using fear-appeals rank among the worst concerning effectiveness in changing behavior (Albarracín, Gilette, Earl, Glasman, Durantini, et al., 2005).

There have been many explanations for the increased risk of adolescents in traffic. These explanations range from psychological and developmental to environmental, but most pertain to risk behavior. In chapter 5 the often heard assumption namely that adolescents respond slower than adults in risky situations is tested in a (traffic) risk setting. Both adolescent and adult males indicated as fast as possible whether actions were a good idea, or not. Actions ranged from 'setting your hair on fire' to 'change directions without looking' and pertained to traffic situations as well as general risks. In this study, participants responded slower to good ideas, and adults responded faster than adolescents in general. According to Fuzzy-Trace Theory (Reyna, 2005) adults process information following a different path than adolescents. Whereas for adolescents most situations are novel and are processed deliberately, rationally and in a detailed manner, adults rely more on gist or intuition. The latter is obviously faster than the former. In traffic, slower reaction times may lead to more risks, which in turn could explain part of the increased risk of the slower adolescents.

In the final chapter, a summary and a discussion of the results of the studies reported in the previous chapters is given. The way adolescents are addressed in safety education could be improved, because we now know that they already feel at risk. Traffic safety is, however, still not high on the adolescents' priority list. Whereas traffic safety education is probably beneficial for the reduction of traffic accidents of adolescents, the development of education programs needs to be more systematic in order for interventions to become successful. Good intentions alone will not change risky behaviors into safe behaviors. 



\section{Samenvatting}

Nederland staat hoog op de ranglijst van de meest verkeersveilige landen in Europa. Toch zijn verkeersongelukken doodsoorzaak nummer een voor adolescenten (12 tot 24-jarigen) in Nederland (net als in Europa en de Verenigde Staten). Adolescentie is de periode waarin een kind lichamelijk volwassen wordt, maar nog niet emotioneel. In Nederland reist deze leeftijdsgroep voornamelijk per fiets, zeker tijdens de middelbare school periode (12 tot 17-jarigen). Hoewel het als een gezonde bezigheid wordt gezien, is fietsen niet zonder risico's. In de Nederlandse provincie Limburg is Het Regionaal Orgaan Verkeersveiligheid Limburg (ROVL) verantwoordelijk voor de preventie van verkeersongevallen.

Het ROVL maakt gebruik van verkeersveiligheidprogramma's die gericht zijn op alle leeftijden, waarbij hun doel is het tot het nulpunt terugdringen van verkeersongevallen en verkeersdoden. Een voorbeeld van een verkeersveiligheidprogramma gericht op middelbare scholieren is Traffic Informers. In dit programma worden scholieren door middel van confronterende video's met soms schokkende beelden van ongevallen gewezen op de gevaren van risicogedrag in het verkeer. Daarna horen ze het verhaal van een verkeersslachtoffer, aan wie ze ook vragen kunnen stellen. Het programma wordt in heel Limburg gebruikt en maakt vrijwel op iedere school uit van het verkeersonderwijs curriculum. Het geldt daarom als een succesvol programma. De Universiteit Maastricht is door het ROVL gevraagd de effecten van het Traffic Informer programma op het gedrag van scholieren te evalueren. Dit proefschrift is een gevolg van deze evaluatie.

In hoofdstuk 1 wordt een beeld geschetst hoe het met de verkeersveiligheid van adolescenten in Nederland is gesteld. Daarnaast worden de beschikbare verklaringen voor het verhoogde risico van tieners in het verkeer uiteengezet. Verder wordt aan de hand van een beschrijving van het Traffic Informer programma het belang van systematische ontwikkeling van voorlichtingsprogramma's over verkeersveiligheid uitgelegd. Tot slot worden kort de beperkingen van het gebruik van angstaanjagende voorlichting genoemd.

De effectevaluatie van Traffic Informers begon met een literatuurstudie naar de achtergronden van risicovol fietsgedrag. Blijkbaar worden ongevallen waarbij fietsers betrokken zijn chronisch niet gerapporteerd, want er zijn vrijwel geen epidemiologische gegevens beschikbaar over gevaarlijk fietsgedrag. Vandaar dat tijdens het onderzoek naar gevaarlijke gedragingen van fietsende tieners gebruik is gemaakt van een bestaande vragenlijst, ontwikkeld door de Stichting Wetenschappelijk Onderzoek Verkeersveiligheid (SWOV; Twisk, Vlakveld, 
\& Commandeur, 2007). De vragenlijst was zodanig opgesteld dat de vragen onderverdeeld konden worden in drie soorten onveilig gedrag, namelijk bewuste overtredingen, bewuste fouten, en onbewuste vergissingen (Reason, 1990). Deze onderverdeling van gevaarlijke gedragingen is eerder gebruikt in onderzoek naar gevaarlijk gedrag van automobilisten met de DBQ (Driver Behavior Questionnaire; Reason et al., 1990), maar werd nog nooit gebruikt bij fietsers.

Het doel van het onderzoek beschreven in hoofdstuk 2 was om achter de parametrische eigenschappen van bovenstaande vragenlijst te komen, de relatie met verkeersongevallen en onveilig fietsgedrag te onderzoeken, en of de veronderstelde onderverdeling tussen overtredingen, fouten en vergissingen ook daadwerkelijk zichtbaar zou worden in een grote steekproef van fietsende tieners. De resultaten bevestigden een oplossing met drie factoren, echter wel andere dan de vooronderstelde, namelijk vergissingen (bewuste en onbewuste fouten), gangbare overtredingen (m.a.w. onverschilligheid t.o.v. verkeersregels, zoals het negeren van stoplichten), en buitengewone overtredingen (bijv. rijden onder invloed van drugs). Gangbare overtredingen werden vaker gerapporteerd dan vergissingen en buitengewone overtredingen.

In hoofdstuk 3 werden mogelijke voorspellers van onveilig fietsgedrag onderzocht, waarbij gebruik werd gemaakt van variabelen uit bekende gedragsmodellen, zoals de Theorie van Gepland Gedrag (bijv. attitude, sociale normen, en eigen-effectiviteit; Ajzen, 1991). Door middel van deze voorspellers kan gedrag veranderd worden. De resultaten van het onderzoek lieten zien dat de gemeten sociaal-cognitieve variabelen gevaarlijk fietsgedrag redelijk goed voorspellen. Daarnaast bleek dat mensen die een ongeluk gehad hebben, zich niet veiliger gedragen in het verkeer gedragen dan mensen die nog nooit een ongeluk gehad hebben. Aangezien verder bleek dat tieners hun risicogedrag goed inschatten, was een van de conclusies dat verkeersveiligheidsprogramma's (in ieder geval voor fietsers) zich dus niet moeten richten op risico perceptie, omdat daar niets meer te halen valt. In dit hoofdstuk stel ik voor dat voorafgaand aan de ontwikkeling van nieuwe verkeersveiligheidsprogramma's eerst wordt onderzocht welke factoren samenhangen met onveilig fietsgedrag en de beïnvloeding ervan tot minder risicovol gedrag leidt.

Hoofdstuk 4 beschrijft de evaluatie van Traffic Informers, waarbij het effect van het programma op mogelijke voorspellers van onveilig fietsgedrag werd gemeten. Deelnemers aan het onderzoek vulden voorafgaand en na het Traffic Informer programma vragenlijsten in, die betrekking hadden op onveilig fietsgedrag, onveilig fietsgedragsintenties, en mogelijke voorspellers van gedrag en intentie. Verschillen tussen pre-test en post-test werden vergeleken 


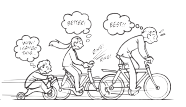

met een controle groep. De resultaten waren teleurstellend; er waren wel significante resultaten, maar deze hadden verwaarloosbare effectgroottes en waren daardoor niet bijster interessant. Deze teleurstellende resultaten zijn te verklaren door onderzoek naar angstaanjagende voorlichting. Hoewel angst erg handig kan zijn om ergens de aandacht op te vestigen, is het gebruik ervan in gezondheidsvoorlichting aan veel beperkingen onderhevig. Hoewel angstaanjagende voorlichting onderaan de lijst van meest succesvolle gedragsveranderende technieken staat, is het gebruik ervan wijdverspreid (Albarracín et al., 2005).

Er bestaan veel verklaringen voor het verhoogde risico van tieners in het verkeer, verschillend van psychologisch tot ontwikkeling gerelateerd, maar voornamelijk hebben ze te maken met risico gedrag. In hoofdstuk 5 namen we een veel gebruikte aanname over tieners in het verkeer onder de loep, namelijk dat tieners in risicosituaties langzamer reageren dan volwassenen. Op een computer probeerden zowel tieners als volwassenen zo snel mogelijk aan te geven of een handeling een goed idee was, of niet. Voorbeelden van handelingen die beoordeeld werden, zijn 'met drugs op gaan fietsen' en 'je hand uit steken bij het afslaan', en hielden zowel betrekking op verkeerssituaties als op algemene risico's (bijv. 'je haar in de brand steken', of 'rauwe kip eten'). In dit onderzoek werd gevonden dat iedereen sneller reageerde als de handeling geen goed idee was (m.a.w. een risico), en dat volwassenen sneller reageerden dan tieners, ongeacht het soort handeling. Deze resultaten zouden verband kunnen houden met het verhoogde risico van tieners in het verkeer, maar zeker weten doen we dat niet.

Het laatste hoofdstuk bestaat uit een samenvatting van de resultaten van de in voorgaande hoofdstukken beschreven onderzoeken, en een discussie over de mogelijke betekenis van de resultaten voor verkeersveiligheidonderzoek en de voorlichting ervan. Ik ben ervan overtuigd dat de manier waarop tieners nu worden aangesproken op hun schijnbaar roekeloze gedrag voor verbetering vatbaar is. Ten eerste voelen tieners zich niet onkwetsbaar en zijn ze zich terdege bewust van de risico's die ze lopen in het verkeer. Verkeersveiligheid staat echter niet hoog op de prioriteitenlijst van tieners. In plaats van met een beschuldigende vinger te wijzen, die slechts defensieve reacties teweeg zal brengen, lijkt het me effectiever om in het verbeteren van het imago van verkeersveiligheid van deze doelgroep te investeren. Daarnaast zijn de huidige verkeersveiligheidsprogramma's goedbedoeld, maar worden ze niet systematisch ontwikkeld en aan een gedegen vooronderzoek onderworpen. Dit komt de effectiviteit niet ten goede. Met slechts goede bedoelingen verandert risicogedrag niet in verantwoord gedrag. 



\section{Acknowledgments}

This story began in 2003 when Jelle started a study group in order to assure his successful graduation. Crowned King Arthur of the Round Table, he assembled his 'knights' and started the quest for the Holy Grail. Graduating meant earning a sword (Excalibur). I guess I should have known that by obtaining a sword, the story had not yet ended. It has been an honor to be a part of this group, and I'm happy to have you with me when I finish my version of this epic tale.

Without the help of many people I would not have written this dissertation. I am grateful for your support. In this section I want to thank some people in particular. If you don't find yourself below, please add yourself.

First and foremost l'd like to thank Rob Ruiter. You got me into this research thing and made me believe in myself and my scientific capabilities every time I was ready to turn my back on a scientific career. It was great to work under your daily supervision.

Dear Gerjo, your leadership skills are inspiring. I'm certain that you have had something to do with the great atmosphere at the department of (work) and social psychology. Thank you for teaching me that motivation should come from the inside, and not from a kick in the butt.

Thank you, mrs. Roberts, for helping me get this many respondents for my study, and for all the great work you do with the Traffic Informers. It's admirable how much time and effort you contribute to the prevention of traffic accidents.

All my colleagues at the department of Work and Social Psychology, thank you for making me feel at home as a Ph.D. student. You made going to work worth while. I miss Friday morning croissants. My successive roommates, Marieke, Jilliebillie, and Loes, thank you for motivating me by preceding me and for showing me how to complete this quest.

Special thanks to my family. There's no way I can ever repay you for the opportunities you have offered me. You have a big part in the completion of my dissertation. Please regard this dissertation as an expression of my gratitude.

Loes and Saar, thank you for being my friends and paranymphs. It sucks to be this far away from you, but I feel much more certain knowing that you have my back at my defense.

Finally, Noukie, thank you for accepting me for who I am, for standing by me, for helping me with the editing of my thesis, and for making me laugh so much. I wouldn't know what else to ask for.

Without you, I would never have finished my Ph.D. candidacy. 



\section{Curriculum Vitae}

Hans Feenstra was born on the 15th of August 1977 in Heemskerk, the Netherlands. He grew up in Uitgeest, Driehuis, and Oegstgeest. In 1996 he obtained his Atheneum diploma from the Rijnlands Lyceum in Oegstgeest. He started studying psychology at Maastricht University in 1997 after spending a year in Israel. He graduated and received his doctorandus degree (master's degree) in Cognitive Psychology, specifically in cognitive ergonomics, in 2004. In January 2006 he started working at the Faculty of Psychology and Neuroscience as a Ph.D. candidate on the research presented in this thesis. Currently he is employed at The Hague University (Haagse Hogeschool) as a teacher in Health Education. 
